\title{
Preneoplastic lesions in rodent kidney induced spontaneously or by non-genotoxic agents: predictive nature and comparison to lesions induced by genotoxic carcinogens
}

\author{
D.R. Dietrich and J.A. Swenberg \\ Departments of Environmental Sciences and Engineering and Pathology, University of North Carolina at Chapel Hill, Chapel Hill, \\ NC 27599 (U.S.A.)
}

Keywords: Non-genotoxic agents; Non-genotoxic carcinogenesis; Kidney; Rodents; Preneoplastic lesions; Progression; Mechanisms

\begin{abstract}
Summary
The current literature on non-genotoxic renal carcinogens and the associated neoplastic and preneoplastic lesions has been reviewed in order to determine their occurrence and predictive nature with regard to tumor formation. In addition the mechanisms involved in the genesis of renal tumors are discussed. A more generalized classification of preneoplastic and neoplastic renal lesions was introduced, based on studies conducted with genotoxic and non-genotoxic renal carcinogens. Reports on preneoplastic lesions were found in the literature for control animals as well as animals treated with non-genotoxic carcinogens. Due to the paucity of data regarding preneoplastic lesions in control animals and animals treated with non-genotoxic carcinogens, new data were also generated by rereading kidney slides of control animals of a randomly selected NTP study and kidney slides of male rats treated with the highest dose of ochratoxin A, one of the most potent non-genotoxic renal carcinogens known. The control slides and the slides from the ochratoxin A study indicated that the cytologic and morphologic types of preneoplastic lesions characteristically observed in bioassays using genotoxic carcinogens are also present in control animals and animals treated with non-genotoxic carcinogens. The incidence of preneoplastic lesions was low in control animals and higher in animals treated with non-genotoxic carcinogens. The diverse classifications used in the literature did not allow a direct comparison of lesions and corresponding incidences with those of the newly generated data. However, three major tendencies were observed: (a) whenever a high incidence of preneoplastic lesions was reported, renal neoplasms were also found, (b) the larger the size and the further a lesion had progressed, the higher was the probability of tumor formation, and (c) not all preneoplastic lesions are irreversible, but reversibility seemed to decrease with increasing lesion size and progression. It
\end{abstract}

Abbreviations: NB, nephroblastoma; RMT, renal mesenchymal tumor; RCT, renal cell tumor; GAPDH, glyceraldehyde-3phosphate dehydrogenase; G6PDH, glucose-6-phosphate dehydrogenase; G6Pase, glucose-6-phosphatase; ALP, alkaline phosphatase; ACP, acid phosphatase; $\gamma$-GT, $\gamma$-glutamyl transpeptidase; $\mathrm{SDH}$, succinate dehydrogenase.

Correspondence: Dr. J.A. Swenberg, Department of Pathology, Campus Box 7095, University of North Carolina at Chapel Hill, Chapel Hill, NC 27599 (U.S.A.). 
must be emphasized that the data available for these conclusions are limited. This is not due to the lack of adequate numbers of bioassays with non-genotoxic carcinogens, but rather to the lack of consistent reporting of data. A generalized and more widely used classification which incorporates early lesions would certainly improve the current data base on renal lesions and provide future improvements in the predictive nature of these lesions.

The most broadly practised approach for evaluating the carcinogenic potential of a chemical and predicting the possible risk of cancer in man is the rodent carcinogenicity bioassay. Such an approach is only of value if the mechanisms of tumor formation in the surrogate species are similar to the mechanisms in man. Nearly all renal tumor types observed in man (Mostofi, 1979; Thoenes et al., 1986) have been experimentally induced in rodents by various chemical carcinogens, hormones, viruses, and radiation (reviewed by Hamilton, 1975; Hiasa and Ito, 1987; Bannasch and Zerban, 1990). The primary endpoint of most experiments conducted with genotoxic carcinogens and essentially all experiments conducted with non-genotoxic carcinogens has been the occurrence of renal tumors, with much less emphasis on preneoplastic lesions.

There is, however, a reasonable amount of literature on the formation and progression of preneoplastic lesions (Hard and Butler, 1970, 1971a,b; Hard, 1979, 1986b; Dees et al., 1980a,b; Lombard et al., 1974; Bannasch et al.. 1974, 1978a,b, 1980; Bannasch, 1986; Tsuda et al., 1983, 1986; Ohmori et al., 1982; Hiasa et al., 1984). All of these studies have been carried out with either genotoxic carcinogens, or within the scope of initiation-promotion experiments using a genotoxic carcinogen as the initiator. Unfortunately, only few comparable assays using several time points have been conducted with non-genotoxic carcinogens (Alden et al., 1981; Alden and Kanerva, 1982a,b; Anderson et al.. 1982; Myers et al., 1982).

It is thus the intention of this paper to review the current literature on preneoplastic lesions of studies conducted with genotoxic carcinogens, hormones, and radiation in order to describe the characteristics and importance of preneoplastic lesions for tumor formation. In addition, a review of selected NTP studies for similar lesions in control animals and carcinogenicity bioassays of non-genotoxic renal carcinogens will be reported. These descriptions will be helpful for placing similar preneoplastic lesions in studies conducted with non-genotoxic carcinogens in proper perspective and may be useful for assessing the predictive value of these preneoplastic lesions for tumor formation. Furthermore, the present day understanding of mechanisms of non-genotoxic carcinogens will be reviewed and set into context with the recorded preneoplastic lesions, providing further insight into non-genotoxic carcinogenesis.

\section{Classification and histopathology of renal tumors and preneoplastic lesions as defined by experi- ments with genotoxic carcinogens, hormones, or radiation}

Major discrepancies exist regarding the classification of renal lesions induced by genotoxic carcinogens. This makes it difficult to compare lesions found in bioassays conducted with genotoxic carcinogens with those observed following exposure to non-genotoxic carcinogens. In order to foster such comparisons, a more generalized classification was devised.

\section{Classification of renal tumors}

Nephroblastomas (NB), like renal mesenchymal tumors (RMT), are neoplasms of young animals (Hard, 1984a,b). Nephroblastomas were experimentally induced in rabbits (Fox et al., 1975; Hard and Fox, 1983), opossums (Jurgelski et al., 1979), mice (Hawks et al., 1974), and rats (Jasmin and Riopelle, 1970; Hawks et al., 1974; Turusov et al., 1980; Hara et al., 1982; Hard, 1985), and were predominantly induced by treating the animals transplacentally or neonatally with 1,2-dimethyl- 
TABLE 1

LIST OF CHEMICALS, ABBREVIATIONS, AND CASNO'S

\begin{tabular}{llr}
\hline Chemicals & Abbreviation & \multicolumn{1}{c}{ Cas-No. } \\
\hline 1,2-Dimethylhydrazine & - & $540-73-8$ \\
1-Methylhydrazine & - & $60-34-4$ \\
1-Ethyl-1-Nitroso-Urea & ENU & $759-73-9$ \\
N-Methyl-N-Nitroso-Urea & MNU & $684-93-5$ \\
Dimethylnitrosamine & DMN & $62-75-9$ \\
Cycasin & - & $14901-08-7$ \\
N-Ethyl-N-Hydroxyethyl & & \\
$\quad$ nitrosamine & EHEN & $13147-25-6$ \\
N-(4'-Fluoro-4-biphenyl) & & \\
$\quad$ acetamide & FBPA & \\
N-Nitrosomorpholin & NNM & - \\
Streptozotocin & - & $1888-89-2$ \\
Lead acetate & - & $301-04-4$ \\
Unleaded Gasoline PS-6 & UG & - \\
2,2,4-Trimethylpentane & TMP & $540-84-1$ \\
1,4-Dichlorobenzene & - & $106-46-7$ \\
d-Limonene & - & $5989-27-5$ \\
Nitrilotriacetate Trisodium Salt & NaNTA & $18662-53-8$ \\
Isophorone & - & $78-59-1$ \\
Ochratoxin A & - & $303-47-9$ \\
\hline
\end{tabular}

hydrazine, 1-methylhydrazine, ENU, MNU, or DMN (for compound abbreviations and CAS numbers see Table 1). RMT, on the other hand, have been the subject of much confusion with respect to diagnosis and classification, the literature revealing no less than 13 synonyms for this complex neoplasm (Hard, 1986a). Most commonly, RMT is mistaken for an embryonal kidney tumor and misclassified as NB or Wilms' tumor. RMT is, however, a distinct entity unrelated to NB, as shown by several experiments with DMN, cycasin, etc. (Jasmin and Riopelle, 1968; Riopelle and Jasmin, 1969; Hard and Butler, 1970). The discriminating features between NB and RMT were reviewed by Hard (1986a). While the literature to date does not indicate the existence of preneoplastic lesions in the pathogenesis of NB, preneoplastic lesions of RMT have been reported in studies conducted with DMN (Hard and Butler, 1970; Driver et al., 1987).

Renal cell tumors (RCT), also known as renal epithelial tumors due to their epigenesis in renal tubule epithelial cells, have been experimentally induced in the rat, mouse, and hamster with genotoxic carcinogens, non-genotoxic carcinogens, hormones, and radiation (reviewed by Hamilton, 1975; Hard, 1986b; Hiasa and Ito, 1987; Bannasch and Zerban, 1990). Perusal of the literature shows that the majority of tumors observed in experiments with non-genotoxic carcinogens are renal cell tumors. For this reason the discussion of preneoplastic lesions will focus on those associated with renal cell tumors rather than NB and RMT.

Sequential observations on the appearance of neoplastic lesions in rats and mice treated with ENU, EHEN, FBPA, and DMN, as well as stopassays carried out with NNM-treated rats, led to the discovery of early lesions with neoplastic characteristics and the identification of at least five different cell types in RCT (Lombard et al., 1974; Hard and Butler, 1971a,b; Dees et al., 1980a,b; Tsuda et al., 1983, 1986; Bannasch et al., 1974, 1978a,b, 1980). These findings, and the similarity of the types of lesions and tumors observed in rodents to tumor types observed in humans, led to renewed investigation and eventually to a tentative new classification of human renal cell tumors (Thoenes et al., 1985, 1986; Stoerkel et al., 1988a,b). The in-depth discussion of these cell types and the corresponding RCT would certainly exceed the scope and the intentions of this review; therefore the reader is referred to the excellent reviews by Bannasch et al. (1989) and Bannasch and Zerban (1990) and the respective references cited in the following paragraphs for more comprehensive information on this matter. However, as most preneoplastic lesions are fairly well characterized by the predominant cell type, biochemical reaction, and appearance, and due to the fact that these characteristics correspond very closely to the ones observed in end-stage RCT, a brief overview of these cell types will be given.

Cytological origin and cytochemical features of cell types found in preneoplastic lesions and RCT

\section{Clear cell}

Serial sections of kidneys of NNM-treated rats revealed the cortical collecting duct and possibly the distal tubule as the origin of the clear cells (Nogueira and Bannasch, 1987; Nogueira et al., 1989; Bannasch et al., 1989). These cells are char- 
acterized by their large translucent cytoplasm, relatively small chromatin-dense nuclei, and irregular shape (Fig. 1, Bannasch et al., 1974, 1978a). Electron microscopically, the clear cells contain only a few mitochondria or profiles of rough endoplasmic reticulum, but an abundance of non-particulate glycogen (Bannasch and Zerban, 1986). Clear cells, as well as clear cell tumors, react strongly positive to PAS staining, demonstrating high concentrations of glycogen in the cytoplasm. Human clear cell tumors, which closely correspond to rat clear cell tumors, have been shown to contain increased amounts of glucose-6-phosphate and high activities of glycogen synthetase and phosphorylase (Mayer and Bannasch, 1988), thus providing further evidence of excessive synthesis and storage of glycogen in preneoplastic and neoplastic lesions.

\section{Acidophilic cell}

Whether the acidophilic cell is an entity by itself or whether it is a prestage to a clear cell is still unknown, although Thoenes et al. (1986) describe it as a separate entity in their refined classification of human renal tumors. In the majority of publications, the acidophilic cell is associated with the clear cell and is considered to have the same origin, i.e., the distal tubule and the cortical collecting duct. Their simultaneous appearance in clear/acidophilic cell tumors of rats treated with NNM also supports this premise (Bannasch et al., 1974, 1978a). A variety of supposedly intermediate stages between acidophilic and clear cells are observed. These intermediate stages incorporate the ultrastructural characteristics of clear and acidophilic cells at the same time (Bannasch et al., 1978a). For simplicity, a distinction between clear cells and acidophilic cells was arbitrarily made by the authors of this review based on the most frequent and well defined cell types observed. Acidophilic cells are slightly larger than normal, polygonal, cylindrical, oval or round, and with a strongly eosinophilic granular or homogeneous cytoplasm (Fig. 2). The chromatin is either dispersed, homogeneous, or focally condensed. A predominant feature is the prominent nucleolus. UItrastructurally, the cytoplasm has a paucity of glycogen and organelles or it contains an abundance of mitochondria. However, unlike the mitochondria in oncocytic cells, these organelles frequently show considerable rarefaction of their cristae and a finely granular dense matrix (Bannasch et al., 1988).

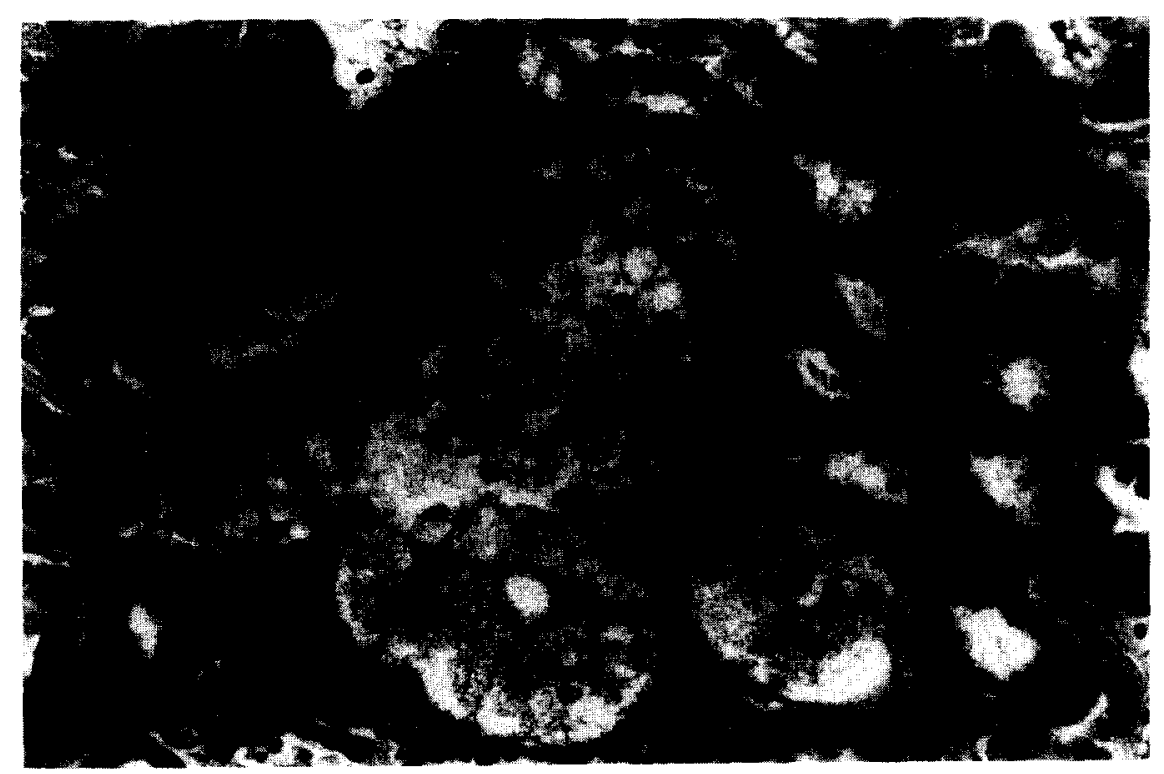

Fig. 1. Atypical tubule containing clear cells. Male rat treated with ochratoxin A $210 \mu \mathrm{g} / \mathrm{kg} /$ day for 2 years. $(80 \times)$ 


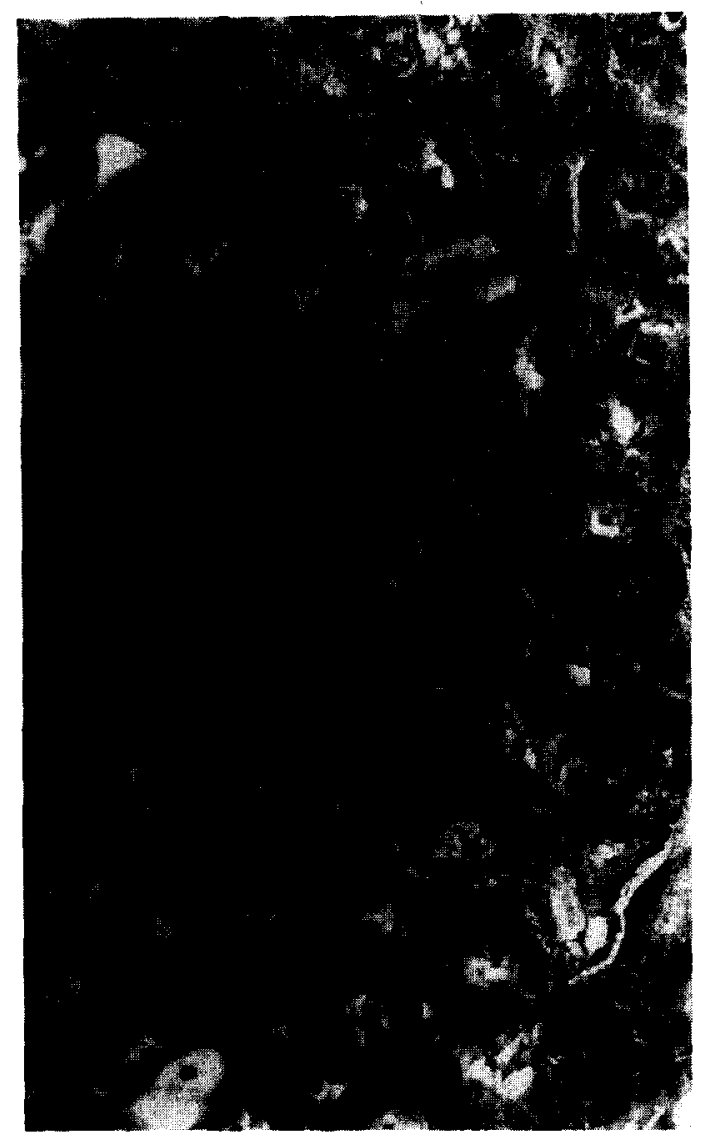

Fig. 2. Atypical tubule containing acidophilic cells. Female rat vehicle control of a 2-year NTP bioassay. $(66 \times)$

\section{Basophilic cell}

The basophilic cell was found to stem from proximal tubule epithelial cells (Bannasch et al., 1974, 1980). Tumors consisting entirely of this cell type have often been described in kidneys of rodents exposed to carcinogens (Mao and Molnar, 1967; Hard and Butler, 1971a,b; McGiven and Ireton, 1972; Bannasch et al., 1980). Histologically these cells are only slightly larger than normal tubule cells, display a marked granular, basophilic cytoplasm due to the abundance of bound and free ribosomes, contain remnants of brush border, and have slightly enlarged, pale to strongly basophilic staining nuclei with prominent nucleolei (Fig. 3, Bannasch et al., 1974). Enzyme histochemical analysis of basophilic cell tubules and tumors found in kidneys of rats treated with nitrosamines or streptozotocin (Bannasch et al., 1986; Tsuda et al., 1985, 1986) revealed for both the tubules and tumors an increase of GAPDH and G6PDH, while demonstrating a reduction or loss of G6Pase, ALP, ACP, $\gamma-\mathrm{GT}$, and SDH compared with controls and the surrounding proximal and distal tubules.

\section{Chromophobic cell}

Chromophobic cells of the rat, as found in chromophobic tubules and chromophobic cell

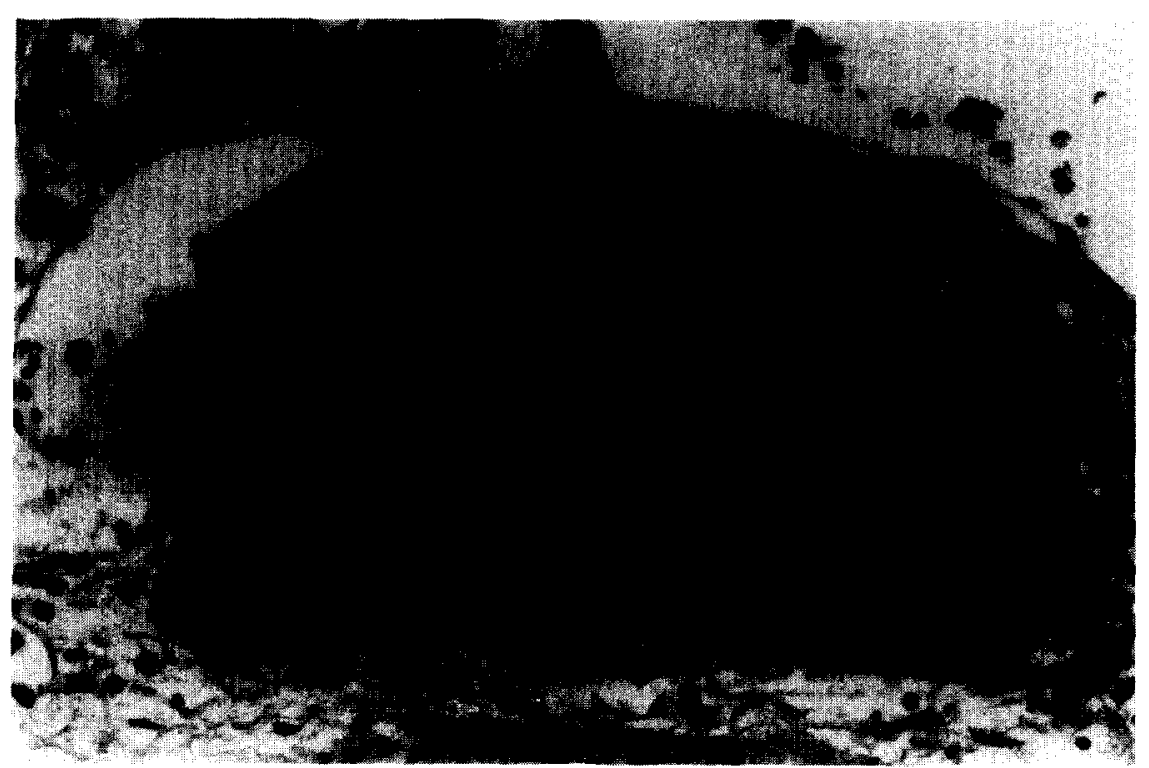

Fig. 3. Atypical hyperplasia containing basophilic cells. Male rat treated with ochratoxin A $210 \mu \mathrm{g} / \mathrm{kg} / \mathrm{day}$ for 2 years. (100 $\times$ ) 


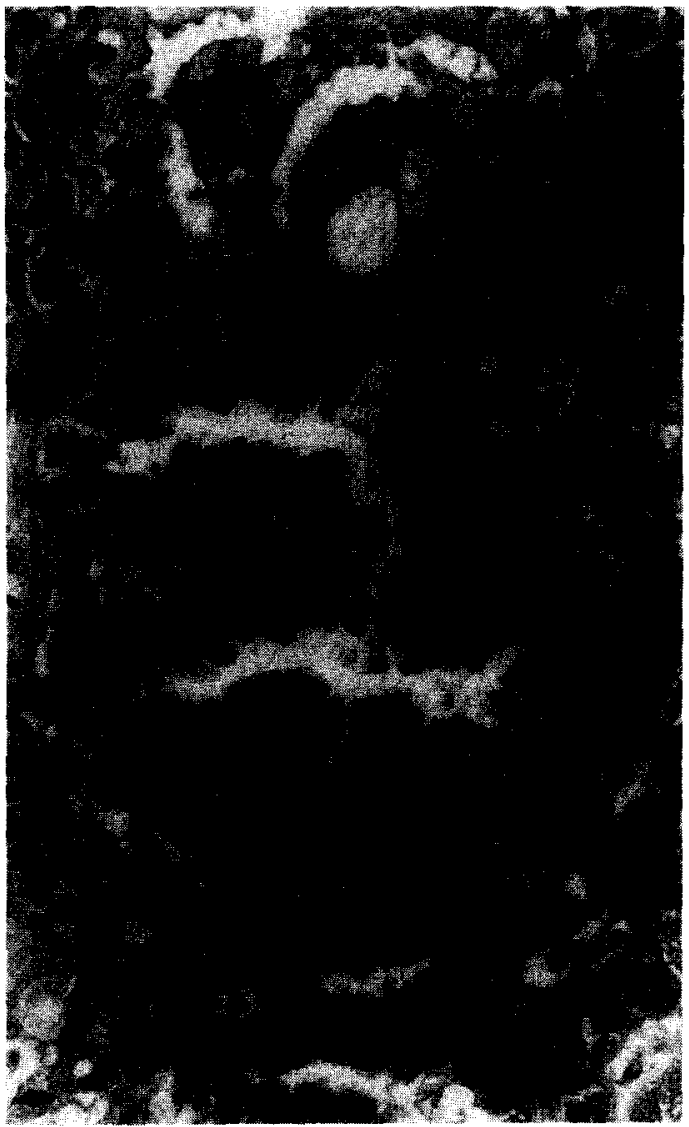

Fig. 4. Atypical hyperplasia containing chromophobic cells. Male rat vehicle control of a 2-year NTP bioassay. $(80 \times)$ tumors, have been shown to originate in proximal tubules (Bannasch et al., 1974, 1979. 1980, 1989; Nogueira, 1987). Histologically chromophobic cells are large with normal staining nuclei, slightly translucent cytoplasm, and sometimes rudimentary remnants of brush border can be found. Stained with Hematoxylin-eosin the cytoplasm reacts with a moderate eosinophilia and basophilia (Fig. 4). The finely reticular cytoplasm stains PAS-negative or weakly positive, indicating very low glycogen content. The staining with Hale's iron colloid is moderate to intense in the entire cytoplasm, and weakly positive with alcian blue. These histochemical reactions suggest an excessive storage of mucopolysaccharides (glycosaminoglycans, proteoglycans), which are probably enclosed in cytoplasmic vacuoles as seen at the ultrastructural level (Bannasch et al., 1988). The same histochemical reactions were demonstrated in chromophobic cell tumors found in rats chronically exposed to streptozotocin and lead acetate (Nogueira, 1987).

\section{Oncocytic cell}

The oncocytic cells or oncocytes originate from the intercalated cells of the collecting duct, as shown by light and electron microscopic studies of

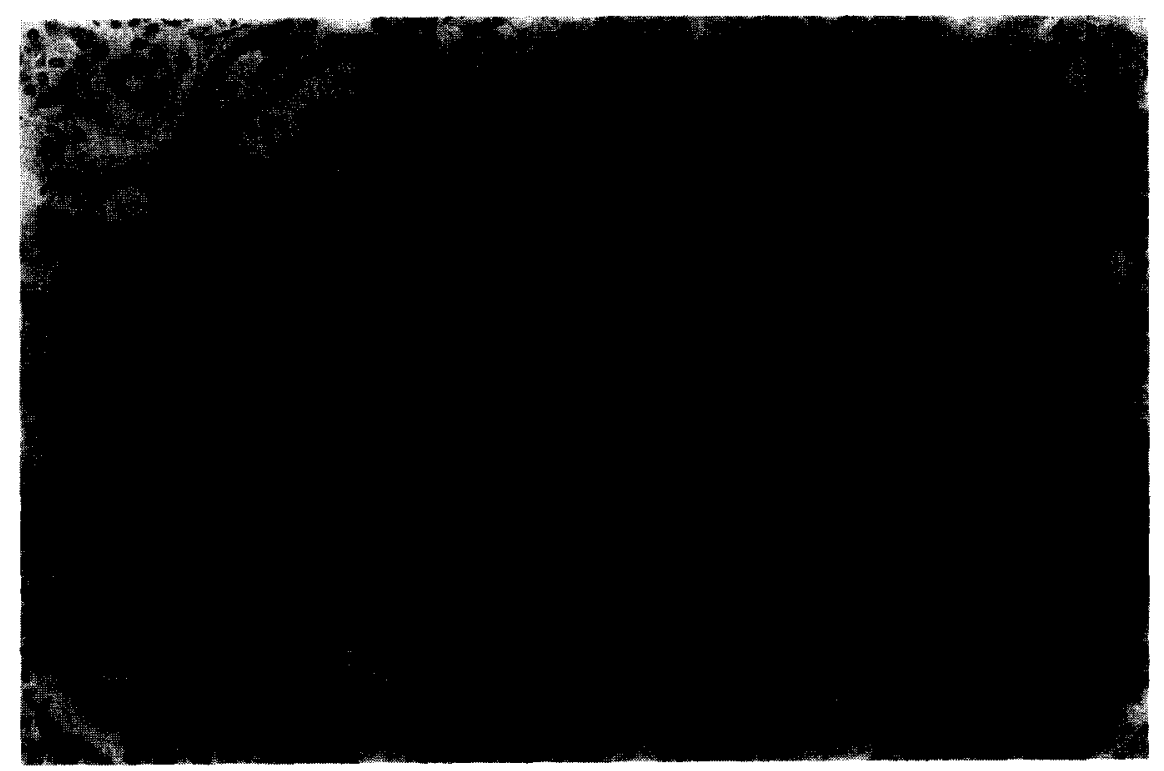

Fig. 5. Atypical hyperplasia containing oncocytic cells. Male rat treated with ochratoxin A $210 \mu \mathrm{g} / \mathrm{kg} / \mathrm{day}$ for 2 years. $(50 \times$ ) 
NNM-, streptozotocin-, or lead acetate-treated rats (Mayer et al., 1989; Nogueira, 1987; Nogueira and Bannasch, 1987, 1988). Light microscopically, these cells are characterized by their large polygonal shape and the intensely acidophilic, finely granular cytoplasm (Fig. 5, Bannasch et al., 1978b). Ultrastructurally, the cytoplasm is crowded with atypical mitochondria which exhibit abundant, unusually long, and densely packed cristae (Krech et al., 1981). Due to the abundance of mitochondria, cytochrome $c$ oxidase, the final enzyme of the mitochondrial respiratory chain, is also found in high quantities. Recently, Mayer et al. (1989) were able to demonstrate cytochrome $c$ oxidase immunohistochemically in oncocytic cells and oncocytomas of rats treated with NNM and in human biopsy tissue, thus making cytochrome $c$ oxidase the ideal biomarker for the detection of oncocytic cell lesions.

\section{Characterization of preneoplastic and neoplastic le- sions}

The literature on preneoplastic and neoplastic lesions of the rat renal epithelium contains vast discrepancies in the classification, i.e., nomenclature of these lesions. Different terminology exists when the lesion type is the same, but the cell type associated with the lesion is different, e.g., altered tubule, in association with basophilic or chromophobic cells (Bannasch et al., 1980), or glycogenotic tubule, in association with clear or acidophilic cells (Bannasch et al., 1978a), or oncocytic tubule, in association with oncocytic cells (Bannasch et al., 1978b). In addition, several terms are applied for an identical lesion, i.e., altered tubule (Tsuda et al., 1985, 1986, 1987), foci of cellular alteration (Dees et al., 1980a,b), dysplastic tubule (McGiven and Ireton, 1972; Ohmori et al., 1982), dysplastic foci (Kurokawa et al., 1988; Hiasa et al., 1984), and atypical tubule (Mao and Molnar, 1967; Ohmori et al., 1982; Bannasch et al., 1978b, 1980), have all been used to describe basophilic cell lesions. In many instances the description or characterization of the preneoplastic and the neoplastic lesion (tumor) was missing. Especially in publications where potentially malignant lesions occurred, it would have been most appropriate had the authors depicted what parameters had been used for dis- tinguishing the various lesions, e.g., adenomas from adenocarcinomas or carcinomas, etc. In view of the rather confusing and indescript nomenclature of preneoplastic and neoplastic lesions, the authors of this review propose a more generalized nomenclature of the preneoplastic and neoplastic lesions. Characterized by their appearance (structure, size, etc.), but not by the predominant cell types, this characterization represents the majority of all lesions considered preneoplastic or neoplastic in the literature arising from renal epithelium in rodents. Individual lesions are characterized and named according to the most frequently used term in the literature. It is hoped that this simplified classification will be incorporated into future bioassays of the NTP, contract and industrial laboratories so that a much better data set can be developed. Synonyms will also be cited along with the respective references.

\section{Atypical tubule}

These tubules are of normal size, but contain altered cell types. Mitotic figures and/or necrotic cells are possible, but rare. The tubular lumen is normal or obstructed with altered cells or debris (Bannasch et al., 1978b, 1980; Shirai et al., 1984; Ohmori et al., 1982; Mao and Molnar, 1967; Figs. 1, 2 and 6).

Synonyms: altered tubule (Tsuda et al., 1985, 1986, 1987); dysplastic tubule (McGiven and Ireton, 1972; Ohmori et al., 1982); foci of cellular alteration (Dees et al., 1980a,b).

\section{Atypical hyperplasia}

This lesion can take on several forms, i.e., it represents a tubule with homogeneous or heterogeneous aggregation of proliferating altered cells that are single- or multi-layered, with or without central necrosis, may or may not have mitotic figures, and is cystic, solid, or dilated in appearance. With exception of the cystic type of atypical hyperplasia, the lesion does not exceed 10 times the size of the surrounding normal tubules and generally involves only one tubule. Compression or infiltration of the surrounding tissue as well as a capsule or pseudocapsule are not observed (Figs. 3, 4, 5 and 7). The cystic type of 


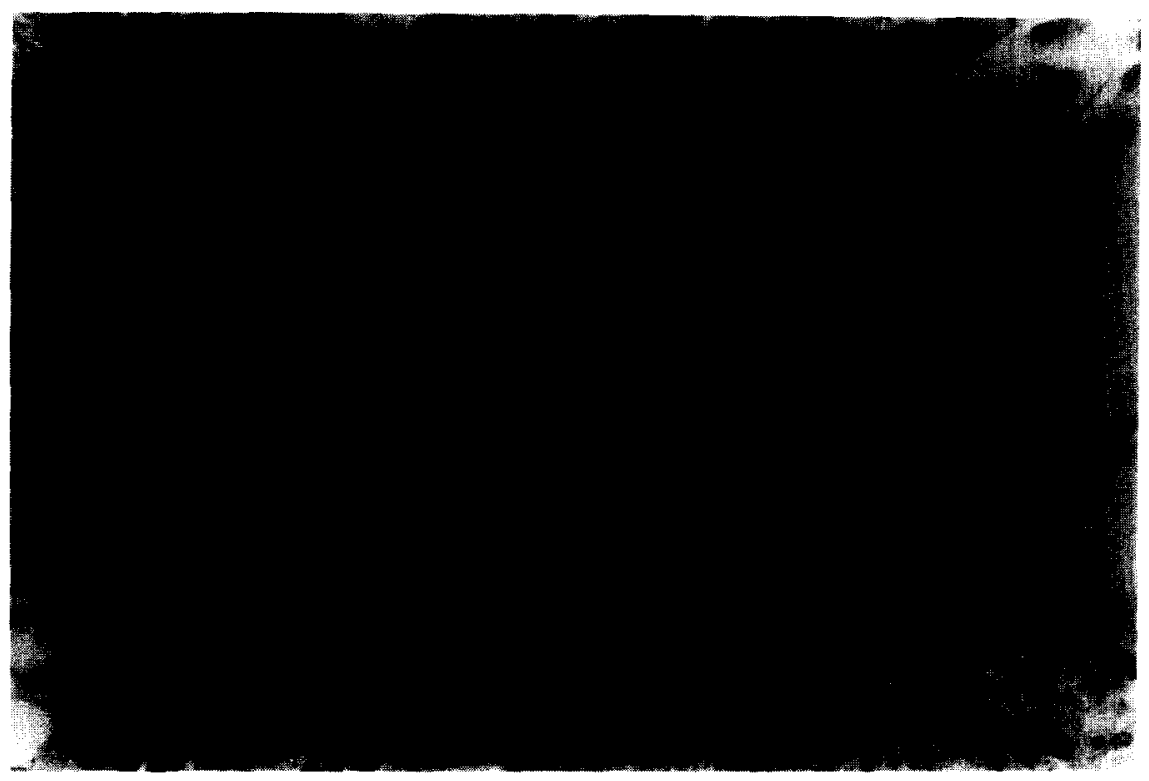

Fig. 6. Atypical tubule containing oncocytic cells. Male rat treated with ochratoxin $\mathrm{A} 210 \mu \mathrm{g} / \mathrm{kg} /$ day for 2 years. (100×)

atypical hyperplasia may be comparable in size to non-preneoplastic cysts but, in contrast to the latter, contains a monolayer or multilayer of altered cells with invaginations or papillary protrusions into the lumen.
Synonyms: dilated hyperplastic tubule (Eker, 1954; Lombard et al., 1974; Hard and Butler. 1971b; Shinohara et al., 1976; Shinohara and Frith, 1980; Bannasch et al., 1978a; MacKay et al., 1987); hyperplastic tubule (Bloom et al., 1963:

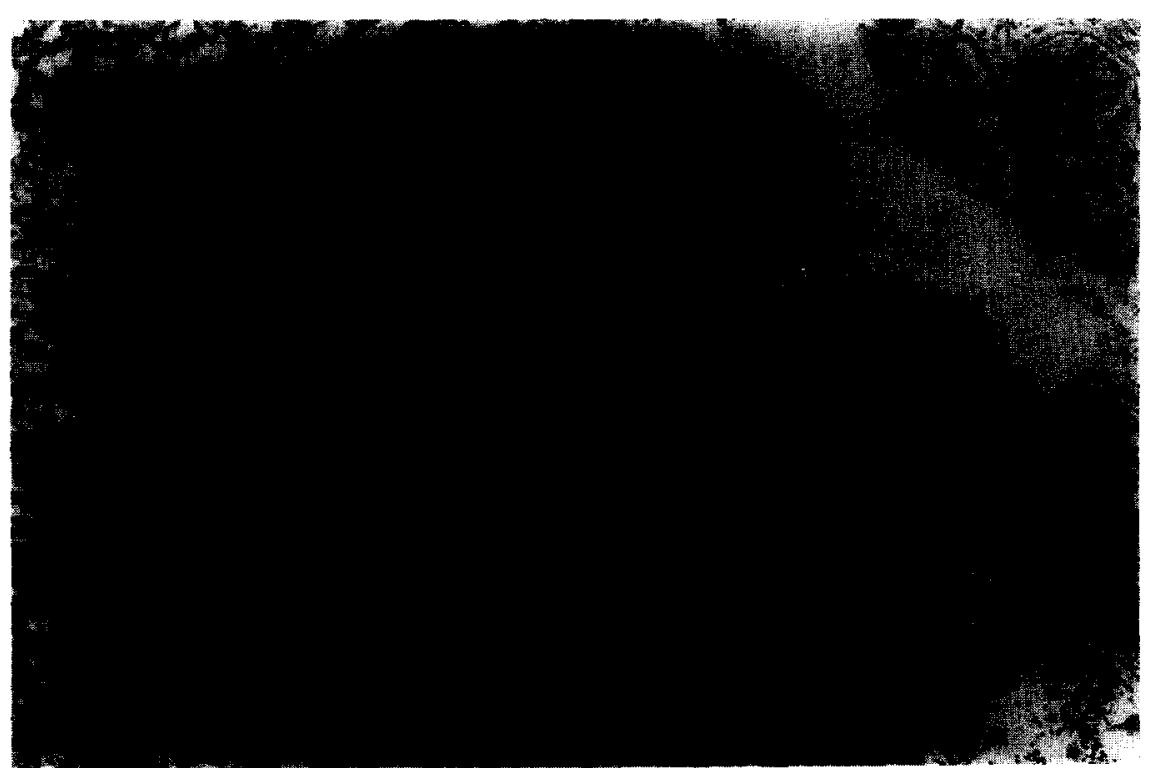

Fig. 7. Atypical hyperplasia containing basophilic cells. Male rat treated with ochratoxin A $210 \mu \mathrm{g} / \mathrm{kg} / \mathrm{day}$ for $2 \mathrm{years}$. $(25 \times$ ) 
Lombard et al., 1974; Bannasch et al., 1978a; Hard and Butler, 1971b; Hard, 1979; Shinohara and Frith, 1980); cystic hyperplasia (Eker, 1954; Mao and Molnar, 1967; Hard and Butler, 1971b; Shinohara et al., 1976; Bannasch et al., 1978a); foci of cellular proliferation (Dees et al., 1980a,b); dysplastic foci (Kurokawa et al., 1983, 1987, 1988; Hiasa et al., 1984); simple hyperplasia (Hiasa et al., 1985); atypical tubule (Ohmori et al., 1982); acinar hyperplasia (MacKay et al., 1987); microepithelioma (Bannasch et al., 1980); microadenoma (Bannasch et al., 1978b; Tsuda et al., 1985, 1987); carcinoma in situ (Dees et al., 1980a,b; Hard, 1986b); adenomatous hyperplasia (Hiasa et al., 1985); atypical cell focus (Short et al., 1989b; Tsuda et al., 1983); dysplastic tubular epithelium (McGiven and Ireton, 1972); renal tubular adenoma (Lipsky and Trump, 1988).

\section{Adenoma}

This lesion may or may not be encapsulated by a very thin layer of fibrous connective tissue, is non-invasive, but the surrounding tissue shows signs of compression (Figs. 8 and 9). Adenomas are composed of either a homogeneous or a heterogeneous altered cell population. Mitotic figures and/or necrotic foci may be observed. Generally, there are three types of adenomas, i.e., the solid, cystic, and cystopapillary type. Solid adenomas appear as massive aggregations of altered cells with either solid, tubular, or cordlike structures. Cystic adenomas (Fig. 10) are large cyst-like lesions with a multilayered, moderately prolific, homogeneous epithelium of pleomorphic appearance. The only distinction between cystadenomas and cystopapillary adenomas is that the latter have papillary invaginations into the cyst lumen (Horn and Stewart, 1952; Eker, 1954; Thomas and Schmähl, 1964; Riopelle and Jasmin, 1969; McGiven and Ireton, 1972; Toth, 1973; Lombard et al., 1974; Hard, 1979; Bannasch et al., 1980; Dees et al., 1980a,b; Shinohara and Frith, 1980; Ohmori et al., 1982; Tsuda et al., 1983, 1985, 1987; Kurokawa et al., 1986, 1987).

Synonyms: clear cell tumor (Hiasa et al., 1984, 1985; Hiasa and Ito, 1987,); dark cell tumor (Hiasa et al., 1984, 1985; Hiasa and Ito, 1987; Kurokawa et al., 1983); epithelioma (Bannasch et al., 1980; Tsuda et al., 1986); hypernephroma (Horn and Stewart, 1952; Thomas and Schmähl, 1964); renal cell tumor (Kurokawa et al., 1983, 1986, 1987, 1988; Hard, 1986b; Short et al., 1989b; Shinohara et al., 1976; Shirai et al., 1984; Ohmori et al., 1982; Hiasa et al., 1984); adenocarcinoma (Richardson, 1957; Hard, 1979, 1986b; Horn and

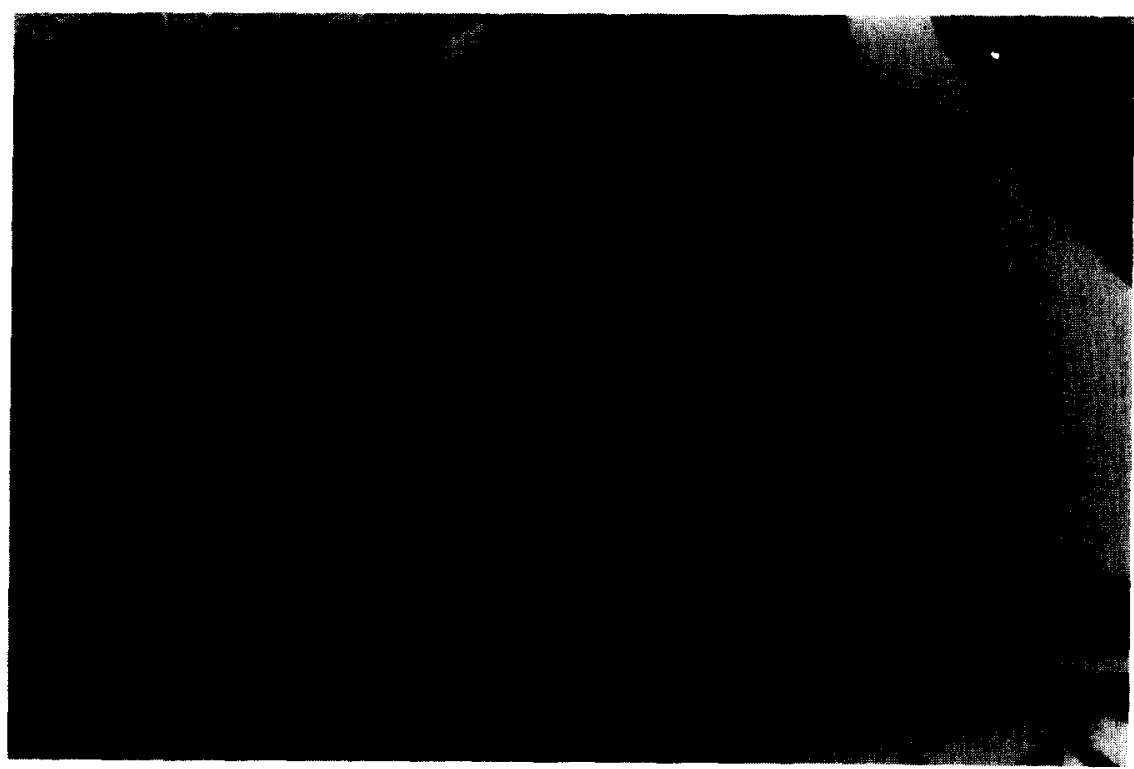

Fig. 8. Adenoma of the basophilic cell type. Male rat treated with ochratoxin A $210 \mu \mathrm{g} / \mathrm{kg} /$ day for 2 years. $(2.5 \times)$ 
Stewart, 1952; Mohr and Hilfrich, 1972; Tsuda et al., 1983; Hiasa et al., 1984, 1985; Kurokawa et al., 1986, 1987); carcinoma in situ (Dees et al., 1980a,b; Hard, 1986b); cyst (Eker, 1954; Shinohara and Frith, 1980); cyst-like (MacKay et al., 1987); microadenoma (Tsuda et al., 1985, 1987); cystic proliferation (Dees et al., 1980a,b).

\section{Carcinoma}

Carcinomas are lesions of varying size, not clearly delineated from the surrounding tissue, that compress and invade the surrounding parenchyma. The lesion can contain only one (homogeneous) or several (heterogeneous) altered cell types (Fig. 11). Mitotic figures and areas of focal necrosis are frequent. The cell types are pleomorphic but not necessarily highly prolific with either

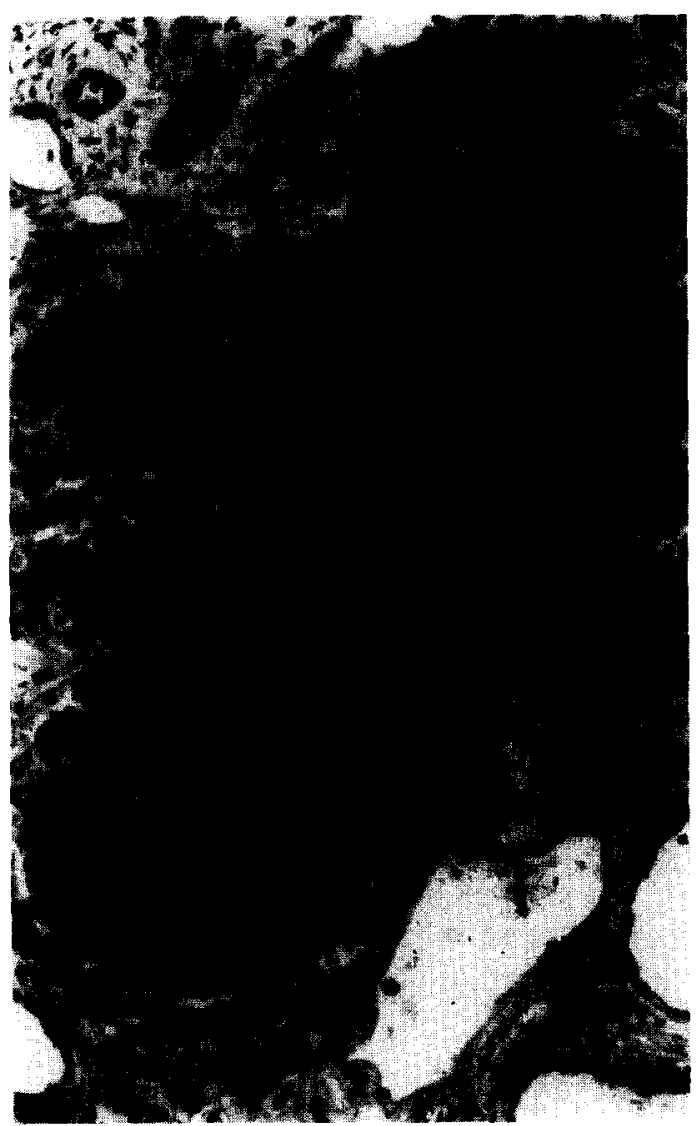

Fig. 9. Adenoma of the basophilic cell type. Male rat vehicle control of a 2-year NTP bioassay. $(50 \times)$

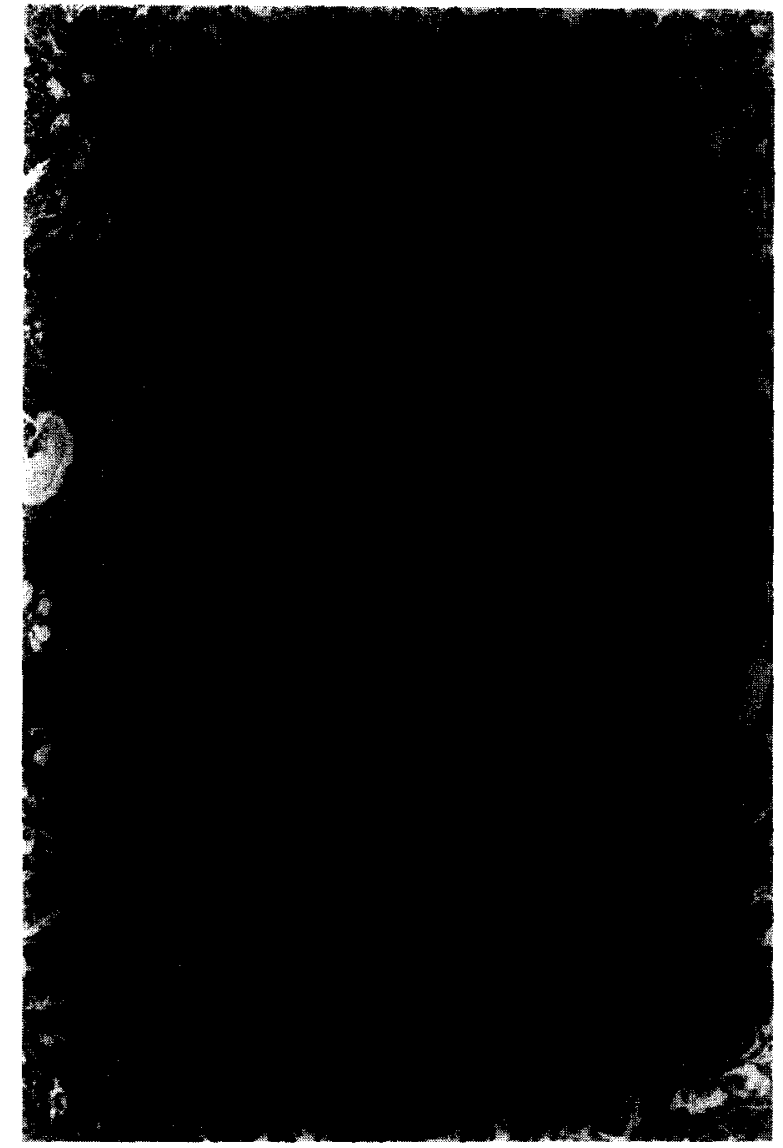

Fig. 10. Cystadenoma of the basophilic type. Mase rat treated with ochratoxin A $210 \mu \mathrm{g} / \mathrm{kg} /$ day for 2 years. $(25 \times)$

a solid, tubular, or papillary growth structure. This lesion metastasizes to other organs (Thomas and Schmäl, 1964; Lombard et al., 1974; Dees et al., 1980a,b; Tsuda et al., 1983; Hard 1986b).

Synonyms: clear cell tumor (Hiasa et al., 1984, 1985; Hiasa and Ito, 1987); dark cell tumor (Hiasa et al., 1984, 1985; Hiasa and Ito, 1987; Kurokawa et al., 1983); epithelioma (Bannasch et al., 1980; Tsuda et al., 1986); hypernephroma (Horn and Stewart, 1952; Thomas and Schmähl, 1964); renal cell tumor (Kurokawa et al., 1983, 1986, 1987, 1988; Hard, 1986b; Short et al., 1989b; Shinohara et al., 1976; Shirai et al., 1984; Ohmori et al., 1982; Hiasa et al., 1984); adenocarcinoma (Richardson, 1957; Hard, 1979, 1986b; Horn and Stewart, 1952; Mohr and Hilfrich, 1972; Tsuda et al., 1983; Hiasa et al., 1984, 1985; Kurokawa et al., 1986, 1987); carcinoma in situ (Dees et al., 


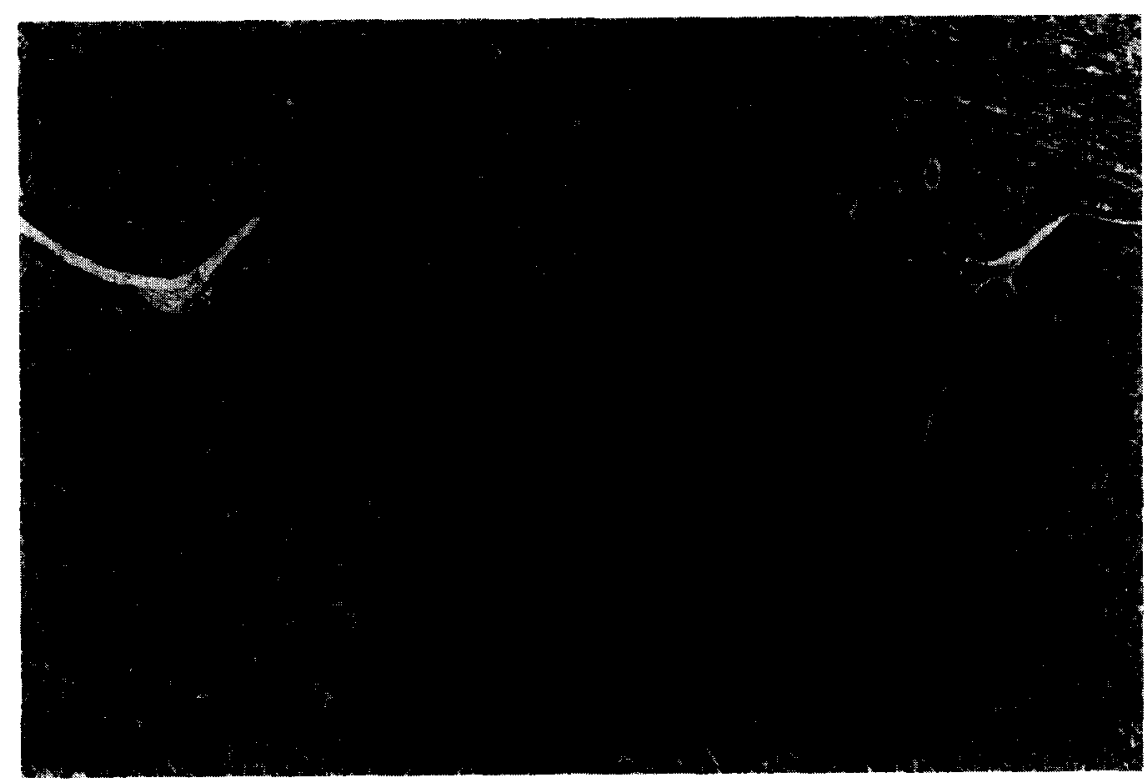

Fig. 11. Mixed cell carcinoma containing acidophilic, basophilic, and oncocytic cells. Male rat treated with ochratoxin A and 210 $\mu \mathrm{g} / \mathrm{kg} /$ day for 2 years. $(16 \times)$

1980a,b; Hard, 1986b); tubulosolid carcinoma (Shinohara and Frith, 1980); tubulopapillary carcinoma (Shinohara and Frith, 1980); tubulopleomorphic carcinoma (Shinohara and Frith, 1980).

\section{Putative progression of preneoplastic lesions}

Several attempts have been made to study the formation of renal tumors and to identify preneoplastic lesions in rodents using sequential- or stop-assays (Hard and Butler, 1971b; Bannasch et al., 1974, 1978a,b, 1980; Dees et al., 1980a,b; Tsuda et al., 1983, 1986). Due to the genotoxic carcinogen chosen for the experiments, preneoplastic lesions preferentially appeared with a specific cell type, while the same preneoplastic lesions were not observed with different specific cell types (Hiasa and Ito, 1987). This not only led to the previously mentioned confusion in the nomenclature of preneoplastic lesions, but also to discrepancies regarding the sequence of progression of some of these preneoplastic lesions. In order to summarize these different observations, the authors of this review recorded and renamed all preneoplastic lesions found in the literature according to the nomenclature introduced above and, based on further information found in the literature, drew a putative scheme of the progression of preneoplastic to neoplastic lesions (Fig. 12). The advantage of this scheme is that it summarizes most of the preneoplastic lesions known to date and suggests which lesions might appear early in the kidneys of rodents exposed to carcinogens.

This scheme is extremely simplified. It should be pointed out that summary terms such as atypi-

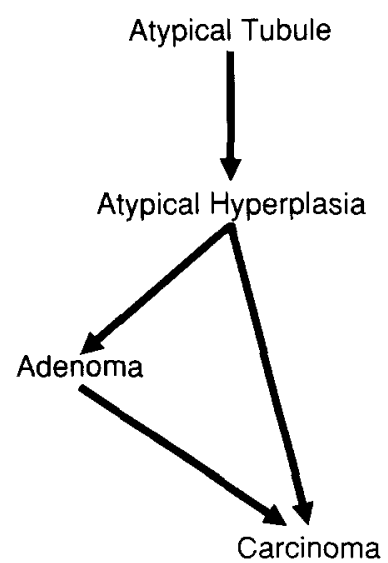

Fig. 12. Schematic of the putative progression of preneoplastic lesions. 
cal hyperplasia or adenoma encompass a number of lesions, e.g., cystic hyperplasia, solid hyperplasia, atypical cell focus, cystadenoma, solid adenoma, cystopapillary adenoma, etc. that could be very well distinguished by the trained pathologist. While a more detailed distinction of individual lesions could enhance understanding the predictive value of such lesions, it would be difficult to ensure consistent classification of such lesions. In light of the fact that this review addresses pathologists conducting routine carcinogenesis bioassays, the summary terms and not the more detailed descriptive terms are used, with the hope that they can be readily incorporated into such studies.

\section{Characterization of non-neoplastic lesions in the kidneys of rodents}

\section{Regenerative hyperplasia}

Regenerative hyperplasia is generally seen as a compensatory response to increased epithelial necrosis induced by cytotoxic chemicals such as unleaded gasoline, 2,2,4-trimethylpentane, isophorone, 1,4-dichlorobenzene, or D-limonene (Short et al., 1987; NTP, 1986, 1987, 1990). Two types of regenerative hyperplasia can be distinguished, simple tubular hyperplasia and hyperplasia associated with the earliest phase of chronic progressive nephrosis (Short et al., 1987).

Simple tubular hyperplasia is characterized by tubules usually decreased in diameter and lined by a single layer of hyperplastic cuboidal epithelial cells. These cells are slightly enlarged, have a basophilic cytoplasm, a high nuclear/cytoplasmic ratio, and sparse brush border. Occasional mitotic figures may be observed, but distinct karyomegaly is generally absent (Short et al., 1986).

\section{Chronic progressive nephrosis}

Chronic progressive nephrosis (CPN) is a common spontaneous disease that varies in severity depending on the rat strain, level of protein in the diet, age and sex of the animal (Gray, 1986). The basic mechanism is apparently a thickening of the basement membrane of glomeruli and tubules. Many chemicals may enhance the incidence, severity, and onset of CPN. When the chemical exposure is also associated with increased prolifera- tive renal tubular lesions. evaluation and separation of induced lesions from those associated with the enhanced nephrosis can be difficult. Regenerative lesions associated with CPN include tubules that have thickened, wrinkled basement membranes, and are lined by enlarged basophilic cells with large nuclei or cells with deeply eosinophilic cytoplasm (Coleman et al.. 1977). The proliferative lesions are often associated with increased thickness of basement membrane and occasionally infiltrates of macrophages and lymphocytes. It is important to separate the regenerative lesions associated with CPN from the chemically induced preneoplastic lesions in any study. This is often most crucial where chemical exposure also causes enhanced nephrosis. Tubules affected with CPN contain populations of epithelial cells that are highly proliferative and may develop neoplasms (Short et al.. 1989a,b; Fig. 13). Thus there may be an increased risk for neoplasia. On the other hand, there are several NTP studies where enhanced nephrosis was found without any increase in renal tubular cell tumors.

\section{Occurrence and incidence of preneoplastic lesions and RCT in control animals}

The current literature revealed that an appreciable amount of knowledge exists regarding the incidence of spontaneous renal tumors in control rats, but only limited information was found regarding the same in control mice. Even less information was available on the spontaneous incidences of preneoplastic lesions in control rats and mice. This is primarily due to the fact that routine bioassays, such as those of the NTP, have not clearly distinguished between regenerative hyperplasia, CPN, and the preneoplastic lesions described earlier in this review. It is imperative that such distinction be incorporated into future studies so that an adequate data base for evaluating the predictability of these lesions for neoplastic endpoints can be generated.

In order to place the occurrence of spontaneous preneoplastic lesions and the incidences thereof in perspective, the authors of this paper reviewed all NTP reports which report the incidences of renal tubular hyperplasia, randomly picked one NTP study and reread all the kidney slides of that 


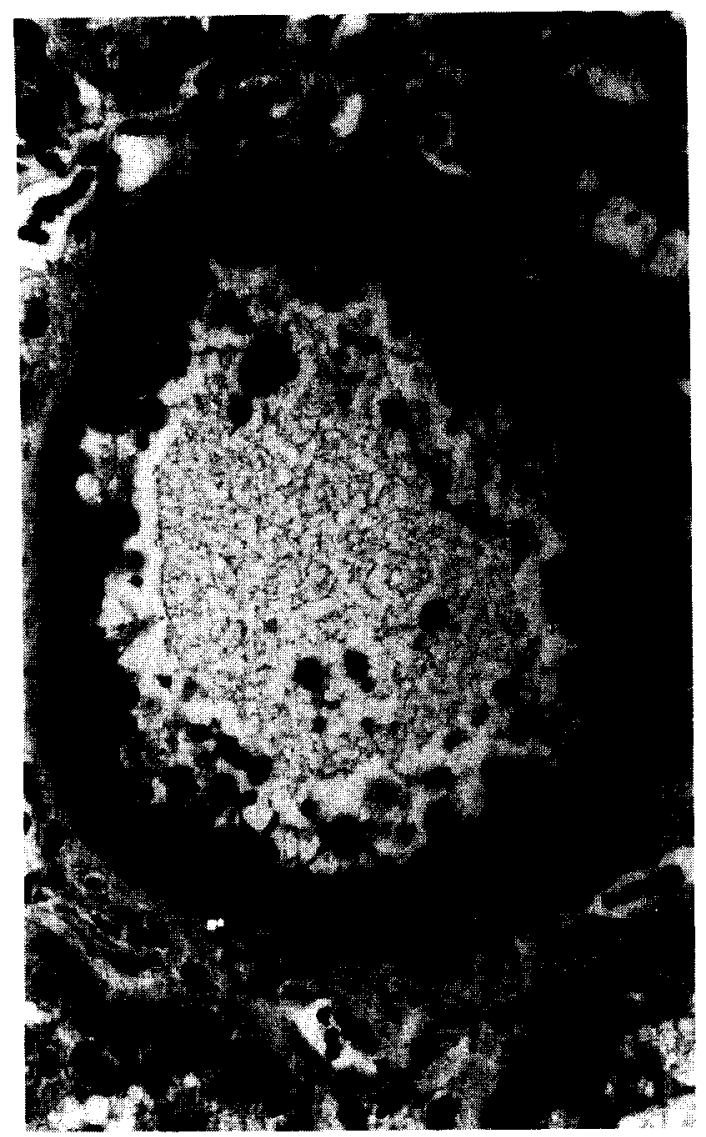

Fig. 13. Basophilic type of atypical hypoplasia arising from tubules affected with chronic progressive nephrosis. Male rat vehicle control of a 2-year NTP bioassay. $(100 \times)$

study, and reviewed the literature regarding preneoplastic lesions. The most prominent "nonneoplastic lesion" found in NTP reports was "renal tubular hyperplasia" (Table 2). This lesion, as described by the NTP (National Toxicology Program, 1990), "is characterized by mild cellular atypia, some variation of nuclear size, and cytoplasm that tends to be basophilic or eosinophilic with granular or foamy appearance. The lesion contains several stratified cell layers, sometimes filling the tubular lumen completely, and involves one to three adjacent normal-sized to slightly enlarged tubules." The description of this lesion corresponds closely to the preneoplastic lesions termed atypical tubule and atypical hyperplasia in this paper. Rereading the kidney slides of control rats and mice of a randomly picked NTP study provided more supportive evidence for the as- sumption that atypical cell types and preneoplastic lesions observed in bioassays with genotoxic carcinogens may be found in control animals regardless of sex and species and thus develop spontaneously. Table 3 compiles the incidences found in the literature with those generated from rereading the slides of the previously mentioned NTP study. A comparison of Table 2 and Table 3 clearly shows that vast discrepancies exist regarding the incidence of preneoplastic lesions in control animals. This problem could be minimized if pathologists would consistently apply a standard classification.

Occurrence and incidence of preneoplastic lesions and RCT in animals treated with non-genotoxic carcinogens

As in control animals, most if not all stages of preneoplastic lesions and altered cell types known from bioassays with genotoxic carcinogens (see above) are found in rodents treated with nongenotoxic carcinogens, e.g., unleaded gasoline (UG), 2,2,4-trimethylpentane (TMP), nitrilotriacetate (NTA), or ochratoxin A (Short et al., 1989b; Alden et al., 1981; Alden and Kanerva, 1982a,b; Miyashiro, 1984; Hiasa et al., 1985; NTP, 1989). The literature concerning incidences of preneoplastic lesions in bioassays with non-genotoxic carcinogens is rather scarce, therefore the information given here is based on the publications of Short et al. (1989b) and Alden and Kanerva (1982b). Additional information was sought by rereading the slides of male rats exposed for 2

TABLE 2

INCIDENCES OF RENAL TUBULAR HYPERPLASIA $\left({ }^{*}\right)$ IN CONTROL AND VEHICLE CONTROL RATS AND MICE OF 2-YEAR BIOASSAYS CONDUCTED BY THE NATIONAL TOXICOLOGY PROGRAM

\begin{tabular}{lll}
\hline Species/Sex & Male & Female \\
\hline Rats & \\
(F344, ACI, Osborne- & \\
$\begin{array}{l}\text { Mendel, Marshall, SD) } \\
\text { Mice }\end{array}$ & $22 / 2959(0.74 \%)$ & $20 / 2950(0.68 \%)$ \\
(B6C3F1, Swiss) & $42 / 2352(1.79 \%)$ & $8 / 2370(0.34 \%)$ \\
\hline * & $\begin{array}{l}\text { Renal tubular hyperplasia corresponds to the terms atypical } \\
\text { tubule and atypical hyperplasia used in this review. }\end{array}$
\end{tabular}


TABLE 3

COMPILATION OF THE INCIDENCES OF PRENEOPLASTIC AND NEOPLASTIC LESIONS OF CONTROL RATS AND MICE AS REPORTED IN THE LITERATURE AND FOUND IN THE SLIDES OF NTP REPORT 353 2,4-DICHLOROPHENOL BY THE AUTHORS OF THIS PAPER.

Abbreviations denote: AT (Atypical Tubule); AH (Atypical Hyperplasia); AD (Adenoma); CA (Carcinoma); n.d. (not determined)

\begin{tabular}{|c|c|c|c|c|c|c|c|c|}
\hline Species & Strain & Sex & Duration (wks) & $\mathrm{AT}$ & $\mathrm{AT}$ & $\mathrm{AD}$ & $\mathrm{CA}$ & Ref. \\
\hline$\overline{\text { Rat }}$ & F344 & $\vec{M}$ & $110-116$ & n.d. & n.d. & $5 / 2320$ & $3 / 2320$ & $\bar{a}$ \\
\hline Rat & F344 & $\mathrm{F}$ & $110-116$ & n.d. & n.d. & $1 / 2370$ & $3 / 2370$ & a \\
\hline Rat & Wistar & M & 32 & $0 / 24$ & $0 / 24$ & $0 / 24$ & $0 / 24$ & $\mathrm{~h}$ \\
\hline Rat & F344 & M & 65 & n.d. & $1 / 28$ & $0 / 28$ & $0 / 28$ & $\therefore$ \\
\hline Rat & F344 & $F$ & 65 & n.d. & $2 / 28$ & $0 / 28$ & $0 / 28$ & $\therefore$ \\
\hline Rat & F344 & M & 104 & $5 / 10$ & $0 / 10$ & $0 / 10$ & $0 / 10$ & d \\
\hline Rat & F344 & $\mathrm{M}$ & 104 & $12 / 14$ & $0 / 14$ & $0 / 14$ & $0 / 14$ & d \\
\hline Rat & F344 & M & 104 & $18 / 50$ & $14 / 50$ & $2 / 50$ & $1 / 50$ & c \\
\hline Rat & F344 & $F$ & 104 & $9 / 50$ & $5 / 50$ & $1 / 50$ & $0 / 50$ & e \\
\hline Mouse & $\mathrm{B} 6 \mathrm{C} 3 \mathrm{~F} 1$ & M & 104 & $15 / 50$ & $3 / 50$ & $0 / 50$ & $0 / 50$ & $\mathrm{e}$ \\
\hline Mouse & B6C3F1 & $F$ & 104 & $4 / 50$ & $0 / 50$ & $0 / 50$ & $0 / 50$ & $c$ \\
\hline Mouse & $\mathrm{BALB} / \mathrm{c}$ & $\mathrm{F}$ & 93 & n.d. & n.d. & $11 / 3495$ & $2 / 3495$ & 1 \\
\hline
\end{tabular}

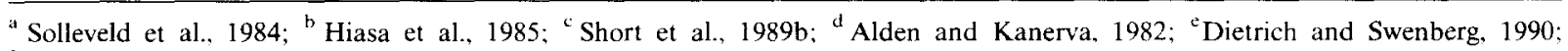

'Shinohara and Frith, 1980.

years to the highest dose $(210 \mu \mathrm{g} / \mathrm{kg} /$ day $)$ of ochratoxin $\mathrm{A}$, one of the most potent non-genotoxic carcinogens known.

The 65-week initiation-promotion study with EHEN and UG or TMP by Short et al. (1989b) also included a promotion control in which F344 rats were exposed to 10,70 , and $300 \mathrm{ppm}$ of UG or $50 \mathrm{ppm}$ of TMP. Although no adenomas or carcinomas were observed, atypical cell foci (corresponding to the term atypical hyperplasia used in this paper) were noted in all groups, i.e., $2 / 27$ $(7.4 \%), 2 / 30(6.7 \%), 4 / 30(13.3 \%)$, and $5 / 28$

TABLE 4

THE INCIDENCES OF LESIONS IN THE RENAL CORTEX OF MALE F344 RATS ${ }^{\text {a }}$ GIVEN A CARCINOGENIC DOSE OF NITRILOTRIACETATE (AS Na $\mathrm{NTA}_{3} \times \mathrm{H}_{2} \mathrm{O}$ ) IN THE DIET FOR 24 MONTHS (CONTINUOUS TREATMENT GROUP) OR ${ }^{b}$ GIVEN IN AN EQUIVALENT DIETARY DOSE (AS H ${ }_{3}$ NTA) FOR 18 MONTHS FOLLOWED BY 6 MONTHS ON THE CONTROL DIET (DISCONTINUED TREATMENT GROUP). THE LESIONS ARE LISTED IN ASCENDING ORDER ON THE BASIS OF FREQUENCY AND TIME/COURSE SEQUENCE. AN APPROXIMATION OF THE ORIGINAL LESION TERMINOLOGY IS MADE WITH THE CURRENT TERMINOLOGY IN ORDER TO FACILITATE COMPARISON (MODIFIED FROM ALDEN AND KANERVA, 1982b)

\begin{tabular}{|c|c|c|c|}
\hline $\begin{array}{l}\text { Current } \\
\text { Nomenclature }\end{array}$ & $\begin{array}{l}\text { Original } \\
\text { Nomenclature }\end{array}$ & $\begin{array}{l}\text { Continuous } \\
\text { Treatment Group }\end{array}$ & $\begin{array}{l}\text { Discontinued } \\
\text { Treatment Group }\end{array}$ \\
\hline Atypical Tubule & Simple Hyperplasia & Clear Cell 96\% & Clear Cell $0 \%$ \\
\hline Atypical Tubule & Simple Hyperplasia & $\begin{array}{l}\text { Eosinophilic }+ \\
\quad \text { Basophilic } 100 \%\end{array}$ & $\begin{array}{l}\text { Eosinophilic }+ \\
\text { Basophilic } 0 \%\end{array}$ \\
\hline Atypical & Nodular Hyperplasia & Clear Cell 57\% & Clear Cell $0 \%$ \\
\hline Hyperplasia & Nodular Hyperplasia & $\begin{array}{l}\text { Eosinophilic }+ \\
\quad \text { Basophilic } 74 \%\end{array}$ & $\begin{array}{l}\text { Eosinophilic }+ \\
\text { Basophilic 0\% }\end{array}$ \\
\hline Atypical & Adenomatous & & \\
\hline Hyperplasia & Hyperplasia & $17 \%$ & $7 \%$ \\
\hline Adenoma & Adenoma & $13 \%$ & $6 \%$ \\
\hline Carcinoma & Adenocarcinoma & $4 \%$ & $4 \%$ \\
\hline
\end{tabular}


$(17.9 \%)$ in the $10,70,300 \mathrm{ppm}$ UG, and $50 \mathrm{ppm}$ TMP groups, respectively. Although not significantly different, the incidences in the promotion control groups were all higher than the $1 / 28$ (3.6\%) observed in the corresponding vehicle control.

In an effort to study the development of tumors induced by high concentrations of NTA, Alden and Kanerva (1982b) reread the kidney slides of F344 males of a 2-year bioassay carried out by the National Cancer Institute. The incidences of preneoplastic and neoplastic lesions observed in the latter study are shown in Table 4. Due to the different terminology used by Alden and Kanerva (1982b) a direct comparison to the terminology proposed in this paper is difficult. The incidences shown in Table 4 are therefore only qualitative. It is clear, however, that a non-genotoxic compound such as NTA can induce a high incidence of preneoplastic lesions of varying cell types. The fact that the incidence is highest for the earliest lesions and lowest for the latest lesions, regarding time/course sequence, suggests that not all early lesions progress further, and that actually the earliest lesions may be reversible as shown in the discontinued treatment group (Table 4).

The incidences of preneoplastic and neoplastic lesions generated by rereading the kidney slides of the high-dose group of male rats exposed to ochratoxin A, suggest a similar incidence/sequence pattern as observed in the study with NTA (Alden and Kanerva, 1982b). High incidences were noted for the earliest lesions, i.e., 100\% (50/50) and 88\% $(44 / 50)$ for atypical tubules and atypical hyperplasia, respectively, while slightly lower incidences were observed for neoplasms, i.e., $32 \%(16 / 50)$ and $64 \%(32 / 50)$ for adenomas and carcinomas, respectively. Due to the different classification terminology used, these incidences do not completely agree with the ones determined by the NTP (Table 5, NTP, 1989). However, despite these differences, Table 5 shows that incidences of lesions such as "cytoplasmic alteration", "hyperplasia", and "proliferation" increase in a dose-dependent fashion. The lesions termed "karyomegaly" in the NTP report (1989) were most likely tubules containing oncocytic cells, as oncocytic cells were observed in $100 \%$ of the slides reread by one of the authors of this review. "Cytoplasmic alteration" probably corresponds to tubules lined with clear and chromophobic cells that would be classified under atypical tubule by the authors of this paper, while "hyperplasia" and "proliferation" appear to correspond to the term atypical hyperplasia. The comparison of terminology used in the ochratoxin A study with that proposed by the authors of this paper emphasizes once again that although preneoplastic lesions are observed in various routine carcinogenesis bioassays, the discrepancy in terminology used for the assessment of lesions prohibits a better understanding of the latter.

\section{Mechanisms of non-genotoxic carcinogens in renal carcinogenesis}

Much research has been conducted in recent years to understand better the mechanisms involved in the induction of neoplasia. These efforts

TABLE 5

INCIDENCES OF RENAL LESIONS IN CONTROL MALE AND FEMALE F344/N RATS AND IN MALE AND FEMALE RATS EXPOSED TO DIFFERENT CONCENTRATIONS OF OCHRATOXIN A IN A NTP TWO-YEAR CARCINOGENESIS BIOASSAY (NTP, REPORT 358, 1989)

Lesions/Dose (microgram $/ \mathbf{k g}$ )

Number of animals examined

Cytoplasmic alteration

Karyomegaly

Hyperplasia

Proliferation

Adenoma

Carcinoma

Metastatic renal carcinoma

\begin{tabular}{cccc} 
Male & & & \\
\hline 0 & 21 & 70 & 210 \\
50 & 51 & 51 & 50 \\
$2 \%$ & $0 \%$ & $5.9 \%$ & $16 \%$ \\
$0 \%$ & $2 \%$ & $100 \%$ & $100 \%$ \\
$2 \%$ & $2 \%$ & $31.4 \%$ & $48 \%$ \\
$0 \%$ & $0 \%$ & $19.6 \%$ & $52 \%$ \\
$2 \%$ & $2 \%$ & $11.8 \%$ & $20 \%$ \\
$0 \%$ & $0 \%$ & $31.4 \%$ & $60 \%$ \\
$0 \%$ & $0 \%$ & $8 \%$ & $26 \%$
\end{tabular}

\begin{tabular}{cccc} 
Female & & & \\
\hline 0 & 21 & 70 & 210 \\
50 & 51 & 50 & 50 \\
$0 \%$ & $0 \%$ & $2 \%$ & $4 \%$ \\
$0 \%$ & $15.7 \%$ & $100 \%$ & $100 \%$ \\
$0 \%$ & $0 \%$ & $24 \%$ & $26 \%$ \\
$0 \%$ & $0 \%$ & $6 \%$ & $32 \%$ \\
$0 \%$ & $0 \%$ & $2 \%$ & $10 \%$ \\
$0 \%$ & $0 \%$ & $2 \%$ & $6 \%$ \\
$0 \%$ & $0 \%$ & $2 \%$ & $0 \%$
\end{tabular}


led to the discovery of many critical events in the etiology of neoplasia, but the actual mechanism(s) responsible for the induction of cancer is not known for a single compound (Swenberg et al., 1990).

Carcinogenesis is known to be a multistep process which involves two or more genetic events and requires cell proliferation (Pitot et al., 1981; Barrett and Wiseman, 1987; Farber and Sarma, 1987; Knudson, 1987; Cerutti, 1988). The genetic events can result from point mutations, chromosomal rearrangements, insertions or deletions of genes, and gene amplification. Cell proliferation is required to convert DNA-damage to point mutations and for clonal expansion of initiated cells. Such clonal expansion increases the probability of additional genetic events occurring in initiated populations, leading to progression (Swenberg et al., 1987; Fig. 14). Non-genotoxic carcinogens obviously do not induce DNA damage themselves. However, non-genotoxic carcinogens can induce enhanced cell proliferation (Short et al., 1987) and thus contribute to enhanced fixation of spontaneous mutations leading to increased numbers of initiated cells, clonal expansion of such initiated cell populations, and to the forma- tion of tumors. Spontaneous mutations are assumed to stem from spontaneous genetic events such as depurination and deamination of DNA. formation of covalent DNA adducts by normal, active cellular metabolites, DNA damage by oxygen free radicals produced in cellular metabolism, and errors in DNA replication (Loeb, 1989). This assumption is corroborated by the observation that control animals from strains of laboratory rodents show an appreciable incidence of spontaneous tumors. This incidence of spontaneous tumors varies greatly from tissue to tissue, strain to strain, sex to sex, and species to species (Swenberg and Short, 1987).

A common feature of non-genotoxic chemicals tested at high doses in carcinogenesis bioassays is the concurrent induction of cytotoxicity and/or hyperplasia in the same tissues of exposed rodents that develop neoplasia. Two of the best known mechanisms by which non-genotoxic carcinogens induce cytotoxicity and the subsequent sustained increase in cell proliferation will be reviewed.

The first and possibly best studied mechanism is the one involved in the chemically induced renal disease known as $\alpha 2$-microglobulin nephropathy. This renal disease was shown to occur only in

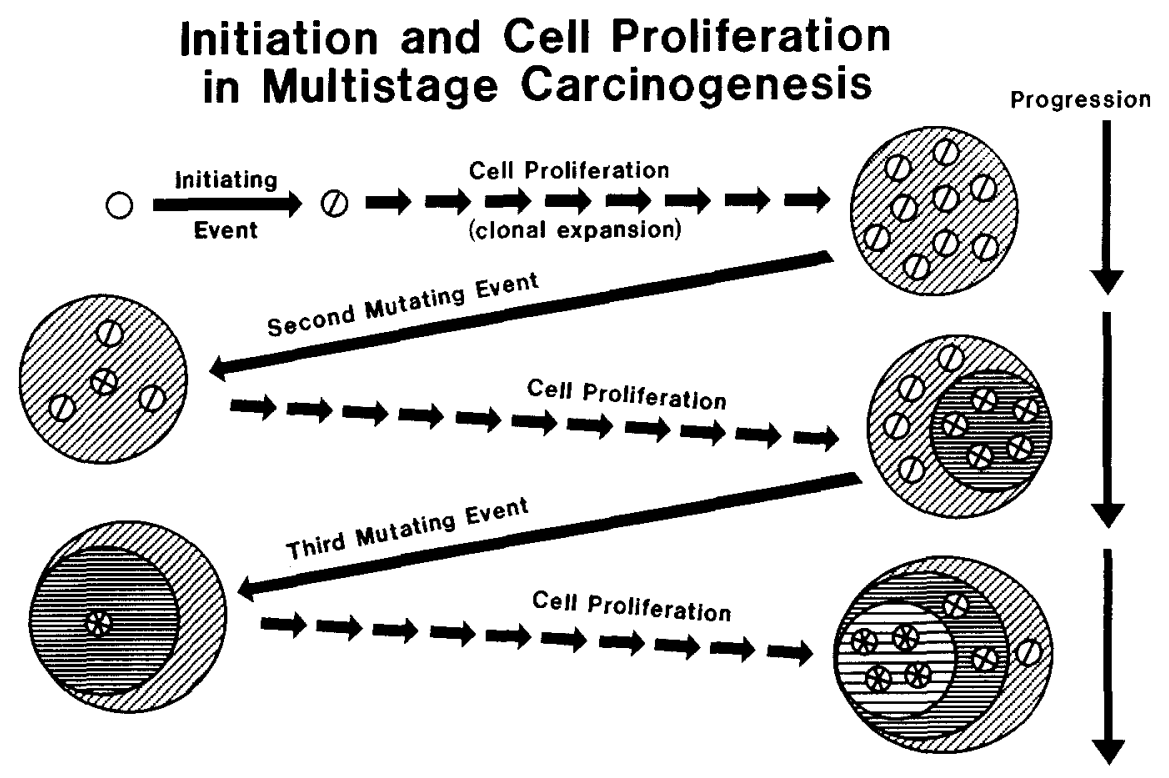

Fig. 14. Schematic of the role of cell proliferation in the initiation, promotion, and progression of carcinogenesis. The extent of clonal expansion necessary for second or third mutational events is dependent on the amount of spontaneous and chemically induced DNA damage (from Swenberg et al., 1987). 
male rats. It does not occur in female rats, either sex of any other rodent species, dogs, or non-human primates (Alden, 1986; Swenberg et al., 1989). It also does not occur in male NBR rats, the only rat strain that does not synthesize this protein (Ridder et al., 1988; Dietrich and Swenberg, 1990). Non-genotoxic chemicals and/or their metabolites that cause this syndrome, e.g., PS-6 unleaded gasoline, D-limonene, 1,4-dichlorobenzene, trimethylpentane, or isophorone, are not cytotoxic by themselves, but bind reversibly to $\alpha 2$-microglobulin, leading to an accumulation of the chemical-protein complex in the iysusomes, cell necrosis, and compensatory cell proliferation.

$\alpha 2-$ Microglobulin is synthesized by the male rat liver, except in NBR rats, at the onset of puberty and excreted in great amounts via the urine (Roy et al., 1966; Neuhaus and Leserth, 1979). Approximately half of the $\alpha 2$-microglobulin is reabsorbed by the proximal tubules of the renal cortex and enzymatically hydrolyzed to amino acids and peptides via lysosomal digestion (Maack et al., 1985). Possibly due to the relatively high resistance of $\alpha 2$-microglobulin toward catabolism (Charbonneau et al., 1988; Lehman-McKeeman et al., 1990), this protein has a natural tendency to accumulate in the lysosomes of the $\mathrm{P}_{2}$ segment of the proximal tubules (Short et al., 1987; Burnett et al., 1989). Hyaline droplets observed in hematoxylin-eosin-stained tissue sections of control male rats often represent lysosomal accumulations of $\alpha 2$-microglobulin. This site-specific accumulation of $\alpha 2$-microglobulin can elicit slightly higher cell turnover of the affected cells in the $\mathrm{P}_{2}$ segment of control male versus female rats (Short, 1988).

The reversible binding of chemical and/or their metabolites to $\alpha 2$-microglobulin, however, is thought to alter the protein, making it even less digestible (Borghoff et al., 1990). This results in an exacerbated accumulation of altered $\alpha 2$-microglobulin in the lysosomes and in increased cell necrosis within the $\mathrm{P}_{2}$ segment, which is thought to be due to a combination of lysosomal dysfunction, release of digestive enzymes into the cytoplasm, and decreased plasma membrane availability (Short et al., 1989a). Male rats treated with PS-6 unleaded gasoline or trimethylpentane were shown to compensate for the enhanced loss of proximal tubule cells by increasing the rate of cell

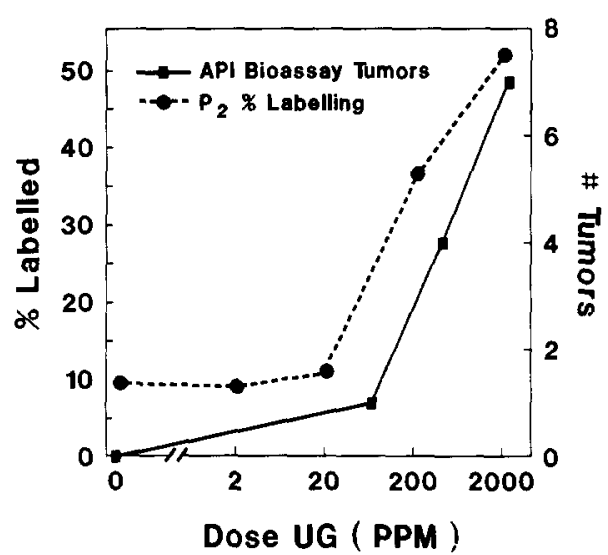

Fig. 15. Dose-dependent similarity of $P_{2}$ cell labeling index observed in male rat kidney during 3 weeks of inhalation exposure to unleaded gasoline and the number of renal epithelial tumours found in male rats exposed to unleaded gasoline for 2 years (from Short et al., 1987).

proliferation in the $P_{2}$ segment. This sustained increase in cell proliferation exhibited a dose response similar to that of renal tumor induction observed in male rats treated with unleaded gasoline in a 2-year bioassay (Short et al., 1986, 1987; Fig. 15). In an ensuing 65-week initiation-promotion study with EHEN as the initiator and unleaded gasoline or trimethylpentane as the promotor, preneoplastic lesions such as atypical hyperplasia of basophilic, eosinoplilic, and clear cell types were observed in the initiation-promotion, initiation-control, as well as in the promotion-control group (Short et al., 1989b), thus supporting the hypothesis that enhanced cell proliferation following treatment with a non-genotoxic chemical can give rise to preneoplastic lesions.

The second mechanism occurs in either sex of rat and mouse and is associated with chronic exposure to nitrilotriacetates ( $\mathrm{Li}$ et al., 1987; Anderson et al., 1982). High concentrations of nitrilotriacetate trisodium salt (NaNTA) have been shown to induce sustained cytotoxicity, preneoplastic lesions, and tumors. The earliest lesions observed are cells with cytoplasmic vacuolization, followed by sloughing and necrosis or proliferation of these cells, and the formation of hyperplastic foci of the eosinophilic, basophilic or clear cell type (Alden et al., 1981; Hiasa et al., 1984, 1985; Miyashiro, 1984). These latter lesions are thought to be precursors of the eosinophilic, basophilic, 
and clear cell adenomas and adenocarcinomas found in rats and mice chronically exposed to NTA (Alden and Kanerva, 1982a,b). NTA, which is not metabolized in the mammalian system, is assumed to induce a redistribution of systemic zinc, leading to an increased resorption of zinc in the proximal tubules of the kidney. This sitespecific increase in tissue zinc has been demonstrated to be a necessary condition for both the initiation and the progression of the NTA-associated renal tubular toxicity which precedes and accompanies neoplasias at this site (Anderson et al., 1982; LeBoeuf et al., 1990a,b).

\section{Discussion}

This report has reviewed the preneoplastic and neoplastic lesions reported from bioassays with genotoxic carcinogens and compared these to lesions observed in control animals and in animals treated with non-genotoxic carcinogens. Lesions of comparable cell type and morphology were found in all animals, whether they were exposed to genotoxic or non-genotoxic carcinogens, or controls. Having established that preneoplastic lesions are present in bioassays with non-genotoxic carcinogens, it must be questioned whether the present knowledge of lesions, e.g., atypical tubule and atypical hyperplasia, is complete enough to assume that these lesions represent precursors of tumors. If they are considered to be preneoplastic lesions, they should be evaluated along with adenomas and carcinomas in routine pathological assessment of carcinogenicity bioassays in order to have a more complete understanding of potential carcinogenicity.

The data presented in this review indicate that non-genotoxic carcinogens induce significantly higher incidences of atypical tubules, atypical hyperplasia, adenoma, and carcinoma (Tables 3, 4, 5) than is found in corresponding controls. As atypical tubules and atypical hyperplasia contain altered cell types similar to those found in adenomas and carcinomas it seems feasible to assume that these early lesions represent tumor precursors. The NTA study reviewed by Alden and Kanerva (1982b, Table 4) as well as the incidences of early lesions compiled from the ochratoxin A bioassay (Table 5) suggest that

\section{Probability Of Neoplastic Progression Of Renal Lesions}
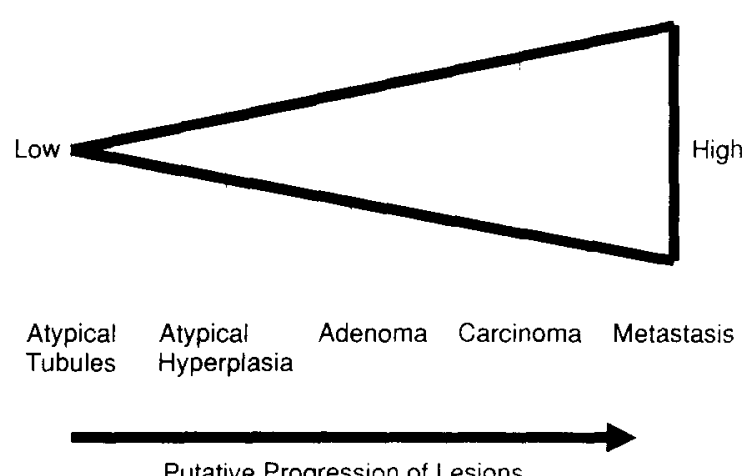

Fig. 16. Schematic of the probabilitjes of the individual preneoplastic and neoplastic lesions for progressing to carcinomas.

whenever high incidences of early lesions are recorded, relatively high incidences of adenomas and carcinomas are also found. This does not imply, however, that all of the early lesions are irreversible and therefore progress to tumors. On the contrary, there are indications that many of the earliest lesions may be reversible (Table 4). although the more advanced the lesions are, the less reversible they appear (Alden and Kanerva, 1982b). Thus it seems that the probability of neoplastic progression of renal lesions increases with the size and progressional stage of the lesion (Fig. 16). The importance of lesion size in tumorigenesis and malignancy of the lesion was also reported by Hard (1984c) in rats treated with a single dose of DMN.

It should be emphasized that the impressions reported above are severely limited by the present data base. The paucity of data is not primarily due to the lack of experiments with non-genotoxic carcinogens, but rather by the lack of consistent reporting of data. A generalized and more widely used terminology that incorporates early lesions would certainly improve the current data base on renal lesions and provide future improvements in the predictive nature of these lesions. In addition to a generalized terminology, bioassays to study the genesis of tumors following exposure to nongenotoxic carcinogens would enhance the under- 
standing of mechanisms involved in the carcinogenesis of non-genotoxic carcinogens. Stop-assays conducted solely with non-genotoxic carcinogens, i.e., without the use of a genotoxic carcinogen as initiator, following a similar protocol as introduced by Bannasch et al. (1974), would shed further light on the time/course sequence of preneoplastic lesions. Furthermore, a bioassay studying the reversibility of early lesions would enhance the predictive potential of early lesions with regards to tumor formation.

\section{Acknowledgements}

We are indebted to Drs. Gary Boorman and Seichi Imoto of the NTP/NIEHS, Research Triangle Park, for their invaluable input and critical discussion of this paper, as well as for numerous photographs of renal lesions. We would also like to thank the National Toxicology Program for letting us review slides from NTP studies and the support provided by the NTP Archives staff.

\section{References}

Alden, C.L. (1986) A review of unique male rat hydrocarbon nephropathy, Toxicol. Pathol., 14, 109-111.

Alden, C.L., and R.L. Kanerva (1982a) The pathogenesis of renal cortical tumours in rats fed $2 \%$ trisodium nitrilotriacetate monohydrate, Food Chem. Toxicol., 20, 441450.

Alden, C.L., and R.L. Kanerva (1982b) Reversibility of renal cortical lesions induced in rats by high doses of nitrilotriacetate in chronic feeding studies, Food Chem. Toxicol., 20, 935-937.

Alden, C.L., R.L. Kanerva, R.L. Anderson and A.G. Adkins (1981) Short-term effects of dietary nitrilotriacetic acid in the male Charles River rat kidney, Vet. Pathol., 18, 549-559.

Anderson, R.L., C.L. Alden, and J.A. Merski (1982) The effects of nitrilotriacetate on cation disposition and urinary tract toxicity, Food Chem. Toxicol., 20, 105-122.

Bannasch, P. (1986) Preneoplastic lesions as end points in carcinogenicity testing. II. Preneoplasia in various nonhepatic tissues, Carcinogenesis, 7, 849-852.

Bannasch, P., and H. Zerban (1986) Renal cell adenoma and carcinoma, in: T.C. Jones, U. Mohr and R.D. Hunt (Eds.), Monographs on Pathology of Laboratory Animals, Urinary System, Springer-Verlag, Berlin, Heidelberg, New York, pp. 112-139.

Bannasch, P., and H. Zerban (1990) Animal models and renal carcinogenesis, in: J.N. Eble (Ed.), Contemporary Issues of Surgical Pathology, Churchill Livingstone, New York, pp. $1-34$.
Bannasch, P., U. Schacht and E. Storch (1974) Morphogenese und Mikromorphologie epithelialer Nierentumoren bei Nitrosomorpholin-vergifteten Ratten. I. Induktion und Histologie der Tumoren, Z. Krebsforsch., 81, 311-331.

Bannasch, P., R. Krech and H. Zerban (1978a) Morphogenese und Mikromorphologie epithelialer Nierentumoren bei Nitrosomorpholin-vergifteten Ratten. II. Tubuläre Glykogenose und die Genese von klar- und acidophilzelligen Tumoren, Z. Krebsforsch., 92, 63-86.

Bannasch, P., R. Krech and H. Zerban (1978b) Morphogenese und Mikromorphologie epithelialer Nierentumoren bei Nitrosomorpholin-vergifteten Ratten. III. Onkocytentubuli und Onkocytome, Z. Krebsforsch., 92, 87-104.

Bannasch, P., D. Mayer and R. Krech (1979) Neoplastische und präneoplastische Veränderungen bei Ratten nach einmaliger oraler Applikation von $\mathrm{N}$-Nitrosomorpholin, J. Cancer Res. Clin. Oncol., 94, 233-248.

Bannasch, P., R. Krech and H. Zerban (1980) Morphogenese und Mikromorphologie epithelialer Nierentumoren bei Nitrosomorpholin-vergifteten Ratten. IV. Tubuläre Läsionen und basophile Tumoren, J. Cancer Res. Clin. Oncol., 98, 243-265.

Bannasch, P., H.J. Hacker, H. Tsuda and H. Zerban (1986) Aberrant carbohydrate metabolism and metamorphosis during renal carcinogenesis, Adv. Enzyme Regul., 25, 279296.

Bannasch, P., E. Nogueira, H. Zerban, K. Beck and D. Mayer (1988) Sequential phenotypic conversion of renal epithelial cells during neoplastic development, in: F. Feo, P. Pani, A. Columbano and R. Garcea (Eds.), Chemical Carcinogenesis, Plenum, New York, pp. 209-215.

Bannasch, P., E. Nogueira and H. Zerban (1989) Zytologie und Zytogenese experimenteller epithelialer Nierentumoren, Verh. Dtsch. Ges. Path., 73, 301-313.

Barrett, J.C., and R.W. Wiseman (1987) Cellular and molecular mechanisms of multistep carcinogenesis: relevance to carcinogen risk assessment, Environ. Health Perspect., 76, $65-70$.

Bloom, H.J.G., C.E. Dukes and B.C.V. Mitchley (1963) Hormone dependent tumours of the kidney. I. The oestrogen induced renal tumour of the Syrian hamster. Hormone treatment and possible relationship to carcinoma of the kidney in man, Br. J. Cancer, 17, 611-645.

Borghoff, S.J., B.G. Short, and J.A. Swenberg (1990) Biochemical mechanisms and pathobiology of alpha2-microglobulin nephropathy, Annu. Rev. Pharmacol. Toxicol., 30, 349-367.

Burnett, V.L., B.G. Short and J.A. Swenberg (1989) Localization of alpha2-microglobulin within protein droplets of male rat kidney: Immunohistochemistry using perfusionfixed, GMA-embedded tissue sections, J. Histochem. Cytochem., 37, 813-818.

Cerutti, P.A. (1988) Commentary. Response modification creates promotability in multistage carcinogenesis, Carcinogenesis, 9, 519-526.

Charbonneau, M., J. Strasser, S.J. Borghoff and J.A. Swenberg (1988) In vitro hydrolysis of $\left[{ }^{14} \mathrm{C}\right]$-alpha2-microglobulin isolated from male rat kidney, Toxicologist, 8, 537.

Coleman, G.L., S.W. Barthold, G.W. Osbaldiston, S.J. Foster 
and A.M. Jonas (1977) Pathological changes during aging in barrier-reared Fischer 344 male rats, J. Geront., 32. $258-278$.

Dees, J.H., B.M. Heatfield, M.D. Reuber and B.J. Trump (1980a) Adenocarcinoma of the kidney. III. Histogenesis of renal adenocarcinomas induced in rats by $N$-(4'-fluoro-4biphenylyl)acetamide, J. Natl. Cancer Inst., 64, 1537-1545.

Dees, J.H., B.M. Heatfield and B.J. Trump (1980b) Adenocarcinoma of the kidney. IV. Electron microcopic study of the development of renal adenocarcinomas induced in rats by $N$-(4'-fluoro-4-biphenylyl)acetamide, J. Natl. Cancer Inst., $64,1547-1562$.

Dietrich, D.R., and J.A. Swenberg (1990) NBR males fail to develop renal disease following exposure to agents that induce alpha2-microglobulin (A2 $\mu$ ) nephropathy, Toxicologist, $10,1064$.

Driver, H.E., I.N.H. White and W.H. Butler (1987) Dose response relationships in chemical carcinogenesis: renal mesenchymal tumours induced in the rat by single dose dimethylnitrosamine, Br. J. Exp. Pathol., 68, 133-143.

Eker, R. (1954) Familial renal adenomas in Wistar rats, Acta Pathol. Microbiol. Scand., 34, 554-562.

Farber, E., and D.R.S. Sarma (1987) Hepatocarcinogenesis: A dynamic cellular perspective, Lab. Invest., 56, 4-22

Fox, R.R., B.A. Diwan and H. Meier (1975) Transplacental induction of primary renal tumours in rabbits treated with 1-ethyl-1-nitrosourea, J. Natl. Cancer Inst., 54, 1439-1448.

Gray, J.E. (1986) Chronic progressive nephrosis, rat, in: T.C. Jones, U. Mohr and R.D. Hunt (Eds.), Monographs on Pathology of Laboratory Animals, Urinary System, Springer-Verlag, Berlin, Heidelberg, New York, pp. 174179.

Hamilton, J.M. (1975) Renal carcinogenesis, Adv. Cancer Res., 22. $1-52$.

Hara, H., M. Miyao, T. Moriki, F. Kutsukake and T. Yamane (1982) Histological and ultrastructural studies of nephroblastoma in rats induced transplacentally by ethylnitrosourea, Acta Pathol. Jap., 32, 385-398.

Hard, G.C. (1979) Effect of age at treatment on incidence and type of renal neoplasm induced in the rat by a single dose of dimethylnitrosamine, Cancer Res., 39, 4965-4970.

Hard, G.C. (1984a) Comparative oncology. I. Nephroblastoma in laboratory mammals, in: C. Pochedly and E.S. Baum (Eds.), Wilm's Tumor. Clinical and Biological Manifestations, Elsevier, New York, pp. 147-167.

Hard, G.C. (1984b) Comparative oncology. II. Nephroblastoma in domesticated and wild animals, in: C. Pochedly and E.S. Baum (Eds.), Wilm's Tumor. Clinical and Biological Manifestations, Elsevier, New York, pp. 169-189.

Hard, G.C. (1984c) High frequency, single dose model of renal adenoma/carcinoma induction using dimethylnitrosamine in $\mathrm{Crl}$ :(W)BR rats, Carcinogenesis, 5, 1047-1050.

Hard, G.C. (1985) Identification of a high-frequency model for renal carcinoma by the induction of renal tumours in the mouse with a single dose of streptozotocin, Cancer Res., 45 , $703-708$.

Hard, G.C. (1986a) Mesenchymal tumour, kidney, rat, in: T.C. Jones, U. Mohr and R.D. Hunt (Eds.), Monographs on
Pathology of Laboratory Animals. Uninary System. Springer-Verlag, Berlin, Heidelberg. New York, pp. 61 -71.

Hard, G.C. (1986b) Experimental models for the sequential analysis of chemically induced renal carcinogenesis. Toxicol. Pathol.. 1, 112-122.

Hard. G.C., and W.H. Butler (1970) (ellular analysis of renal neoplasia: Light microscope study of the development of interstitial lesions induced in the rat kidney by a single carcinogenic dose of dimethylnitrosamine. Cancer Res. 30. $2806-2815$

Hard, G.C., and W.H. Butler (1971a) Ultrastructural aspects of renal adenocarcinoma induced in the rat by dimethylnitrosamine, Cancer Res., 31, 366-372.

Hard, G.C., and W.H. Butler (1971b) Morphogenesis of epithelial neoplasms induced in the rat kidney by dimethylnitrosamine, Cancer Res.. 31, 1496-1505.

Hard, G.C., and R.R. Fox (1983) Histologic characterization of renal tumours (nephroblastomas) induced transplacentally in IIIVO $/ \mathrm{J}$ and $\mathbf{W H} / \mathrm{J}$ rabbits by $N$-ethylnitrosourea, Am. J. Pathol., 113, 8-18.

Hawks, A., R.M. Hicks, J.W. Holsman and P.N. Magee (1974) Morphological and biochemical effects of 1,2-dimethylhydrazine and 1-methylhydrazine in rats and mice. $\mathrm{Br}$. J. Cancer, 30, 429-439.

Hiasa, Y., and N. Ito (1987) Experimental induction of renal tumours, CRC Crit. Rev. Toxicol.. 17, 279-343.

Hiasa, Y., N. Enoki, Y. Kitahori, N. Konishi and T. Shimoyama (1984) DL-Serine: promoting acitivity on renal tumourigenesis by $N$-ethyl- $N$-hydroxyethylnitrosamine in rats, $J$. Natl. Cancer Inst.. 73, 297-299.

Hiasa, Y., Y. Kitahori, N. Konishi and T. Shimoyama (1985) Dose-related effect of trisodium nitrilotriacetate monohydrate on renal tumourigenesis initiated with $N$-ethyl- $N$-hydroxyethylnitrosamine in rats, Carcinogenesis, 6, 907-910.

Horn, H.A., and H.L. Stewart (1952) A review of some spontaneous tumours in noninbred mice. J. Natl. Cancer Inst., 13. $591-603$

Jasmin. G., and J.L. Riopelle (1968) Renal adenomas induced by dimethylnitrosamine, Arch. Pathol., 85, 298-305.

Jasmin, G.. and J.L. Riopelle (1970) Nephroblastomas induced in ovariectomized rats by dimethylbenzanthracene. Cancer Res., 30, 321-326.

Jurgelski, W.. P. Hudson and H.L. Falk (1979) Tissue differentiation and susceptibility to embryonal tumour induction by ethylnitrosourea in the opossum. Natl. Cancer Inst. Monogr, 51, 123-158.

Knudson. A.G. Jr. (1987) A two-mutation model for human cancer, in: G. Klein (Ed.), Advances in Viral Oncology, Vol. 7. Raven Press, New York, pp. 1-17

Krech, R., H. Zerban and P. Bannasch (1981) Mitochondrial anomalies in renal oncocytes induced in rat by $N$ nitrosomorpholine, Eur. J. Cell Biol.. 25, 331-339.

Kurokawa, Y.. M. Takahashi, T. Kokubo, Y. Ohno and Y. Hayashi (1983) Enhancement by potassium bromate of renal tumourigenesis initiated by $N$-ethyl- $N$-hydroxyethylnitrosamine in F344 rats, Gann, 74, 607-610.

Kurokawa, Y., S. Takayama, Y. Konishi, Y. Hiasa, S. Asahina, M. Takahashi, A. Maekawa and Y. Hayashi (1986) Long- 
term in vivo carcinogenicity tests of potassium bromate, sodium hypochlorite, and sodium chlorite conducted in Japan, Environ. Health Perspect., 69, 221-235.

Kurokawa, Y., Y. Matushima, N. Takamura, T. Imazawa and Y. Hayashi (1987) Relationship between the duration of treatment and the incidence of renal cell tumours in male F344 rats administered potassium bromate, Jpn. J. Cancer Res., 78, 358-364.

Kurokawa, Y., N. Takamura, Y. Matushima, T. Imazawa and $Y$. Hayashi (1988) Promoting effect of peroxisome proliferators in two-stage rat renal tumourigenesis, Cancer Lett., 43, 145-149.

LeBoeuf, R.A., G.A. Kerckaert, M.J. Aardema, J.A. Poiley and R. Raineri (1990a) Enhanced morphological and neoplastic transformation of Syrian hamster embryo cells cultured at pH 6.70, in: M.L. Mendelsohn and R.J. Albertini (Eds.), Mutation and the Environment, Part E: Environmental Genotoxicity, Risk and Modulation, in press.

LeBoeuf, R.A., E.D. Thompson, G.A. Kerckaert, B.A. Reeder, D.L. Putman and M.J. Morris (1990b) Genotoxicity of zinc chelates of nitrilotriacetic acid (NTA) and EDTA, Environ. Mol. Mutagen., 15, 117.

Lehman-McKeeman, L.D., M.I. Rivera-Torres and D. Caudill (1990) Lysosomal degradation of alpha2-microglobulin and alpha2-microglobulin-xenobiotic conjugates, Toxicol. Appl. Pharmacol., 103, 539-548.

Li, J.L., S. Okada, S. Hamazaki, Y. Ebina and O. Midorikawa (1987) Subacute nephrotoxicity and induction of renal cell carcinoma in mice treated with ferric nitrilotriacetate, Cancer Res., 47, 1867-1869.

Lipsky, M.M., and B.F. Trump (1988) Chemically induced renal epithelial neoplasia in experimental animals, Int. Rev. Exp. Pathol., 30, 357-383.

Loeb, L.A. (1989) Endogenous carcinogenesis: molecular oncology into the twenty-first century - Presidential Address, Cancer Res., 49, 5489-5496.

Lombard, L.S., J.M. Rice and S.D. Vesselinovitch (1974) Renal tumours in mice: light microscopic observations of epithelial tumours induced by ethylnitrosourea, J. Natl. Cancer Inst., 53, 1677-1685.

Maack, T., C.H. Park and M.J.F. Camargo (1985) Renal filtration, transport, and metabolism of proteins, in: P.W. Seldin and G. Giebisch (Eds.), The Kidney: Physiology and Pathophysiology, Raven Press, New York, pp. 1773-1803.

MacKay, K., L.J. Striker, C.A. Pinkert, R.L. Brinster and G.E. Striker (1987) Glomerulosclerosis and renal cysts in mice transgenic for the early region of SV40, Kidney Int., 32, $827-837$.

Mao, P., and J.J. Molnar (1967) The fine structure and histochemistry of lead-induced renal tumours in rats, Am. J. Pathol., 50, 571-603.

Mayer, D., and P. Bannasch (1988) Activity of glycogen synthase and phosphorylase and glucose 6-phosphate content in renal clear cell carcinomas, J. Cancer Res. Clin. Oncol., $114,369-372$.

Mayer, D., E. Weber, B. Kadenbach and P. Bannasch (1989) Immunocytochemical demonstration of cytochrome $c$ oxidase as a marker for renal oncocytes and oncocytomas, Toxicol. Pathol., 17, 46-49.
McGiven, A.R., and H.J.C. Ireton (1972) Renal epithelial dysplasia and neoplasia in rats given dimethylnitrosamine, J. Pathol., 108, 187-190.

Miyashiro, A. (1984) Promoting effect of trisodium nitrilotriacetate monohydrate on the development of tumours in kidneys and urinary bladders of rats treated with $N$-ethyl$N$-hydroxyethylnitrosamine or $N$-butyl- $N$-(4-hydroxybutyl)nitrosamine, J. Nara Med. Ass., 35, 550-565.

Mohr, U., and J. Hilfrich (1972) Brief communication: Effect of a single dose of $\mathrm{N}$-diethylnitrosamine on the rat kidney, J. Natl. Cancer Inst., 49, 1729-1731.

Mostofi, F.K. (1979) Tumors of the renal parenchyma, in: J. Churg, B.H. Spargo, F.K. Mostofi and M.R. Abell (Eds.), Kidney Disease: Present Status, National Academy of Pathology Monographs, Williams and Wilkins, Baltimore, MD, pp. 356-412.

Myers, M.C., R.L. Kanerva, C.L. Alden and R.L. Anderson (1982) Reversibility of nephrotoxicity induced in rats by nitrilotriacetate in subchronic feeding studies, Food Chem. Toxicol., 20, 925-934.

National Toxicology Program (1986) Toxicology and carcinogenesis studies of isophorone in F344/ $\mathrm{N}$ rats and B6C3F1 mice, Tech. Rep. Ser., 291.

National Toxicology Program (1987) Toxicology and carcinogenesis studies of 1,4-dichlorobenzene in F344/N rats and B6C3F1 mice, Tech. Rep. Ser., 319.

National Toxicology Program (1989) Toxicology and carcinogenesis studies of ochratoxin $\mathrm{A}$ in F344/ $\mathrm{N}$ rats, Tech. Rep. Ser., 358.

National Toxicology Program (1990) Toxicology and carcinogenesis studies of d-limonene in $\mathrm{F} 344 / \mathrm{N}$ rats and $\mathrm{B} 6 \mathrm{C} 3 \mathrm{~F} 1$ mice, Tech. Rep. Ser., 347.

Neuhaus, O.W., and D.S. Leserth (1979) Dietary control of the renal reabsorption and excretion of alpha2-microglobulin, Kidney Int., 16, 409-415.

Nogueira, E. (1987) Rat renal carcinogenesis after chronic simultaneous exposure to lead acetate and $N$-nitrosodiethylamine, Virchows Arch. B Cell Pathol., 53, 365-374.

Nogueira, E., and P. Bannasch (1987) Histogenese von onkocytären und klarzelligen Nierentumoren der Ratte, Verh. Dtsch. Ges. Pathol., 71, 562-.

Nogueira, E., and P. Bannasch (1988) Cellular origin of rat renal oncocytoma, Lab. Invest., 59, 337-343.

Nogueira, E., F. Klimek, E. Weber and P. Bannasch (1989) Collecting duct origin of rat renal clear cell tumours, Virchows Arch. B Cell Pathol., 57, 275-283.

Ohmori, T., Y. Hiasa, Y. Murata and G.M. Williams (1982) Gamma glutamyl transpeptidase activity in carcinogen-induced epithelial lesions of rat kidney, Gann, 73, 543-548.

Pitot, H.C., T. Goldsworthy and S. Moran (1981) The natural history of carcinogenesis: implication of experimental carcinogenesis in the genesis of human cancer, J. Supramol. Struct. Cell Biochem., 17, 133-146.

Richardson, F.L. (1957) Incidence of mammary and pituitary tumours in hybrid mice treated with stilbestrol for varying periods, J. Natl. Cancer Inst., 18, 813-829.

Ridder, G.N., E.C. von Bargen, R.D. Parker and C.L. Alden (1988) Spontaneous and induced accumulation of alpha2- 
microglobulin in the kidney cortex of rats and mice, Toxicologist, 8,352 .

Riopelle, J.L., and G. Jasmin (1969) Nature, classification, and nomenclature of kidney tumours induced in the rat by dimethylnitrosamine, J. Natl. Cancer Inst., 42, 643-662.

Roy, A.K., O.W. Neuhaus and C.R. Harmison (1966) Preparation and characterization of sex-dependent rat urinary protein, Biochim. Biophys. Acta, 127, 72-81.

Shinohara, Y.. M. Arai, K. Hirao, S. Sugihara, K. Nakanishi, H. Tsunoda and N. Ito (1976) Combination effect of citrinin and other chemicals on rat kidney tumourigenesis, Gann. 67, 147-155.

Shinohara, Y.. and C.H. Frith (1980) Morphologic characteristics of benign and malignant renal cell tumours in control and 2-acetylaminofluorene-treated $\mathrm{BALB} / \mathrm{c}$ female mice, Am. J. Pathol., 100, 455-468.

Shirai, T., M. Ohshima, A. Masuda, S. Tamano and N. Ito (1984) Promotion of 2-(ethylnitrosamino)ethanol-induced renal carcinogenesis in rats by nephrotoxic compounds: Positive responses with folic acid. basic lead acetate, and $N$-(3,5-dichlorophenyl)succinimide but not with 2,3-dibromo-1-propanol phosphate, J. Natl. Cancer Inst., 72. $477-482$.

Short, B.G. (1988) Unleaded gasoline renal carcinogenesis in rats, Dissertation, University of North Carolina Department of Pathology, $185 \mathrm{pp}$.

Short, B.G., V.L. Burnett and J.A. Swenberg (1986) Histopathology and cell proliferation induced by 2,2,4-trimethylpentane in the male rat kidney, Toxicol. Pathol., 14, 194203.

Short, B.G., V.L. Burnett, M.G. Cox, J.S. Bus and J.A. Swenberg (1987) Site-specific renal cytotoxicity and cell proliferation in male rats exposed to petroleum hydrocarbons, Lab. Invest., 57, 654-577.

Short. B.G., V.L. Burnett and J.A. Swenberg (1989a) Elevated proliferation of proximal tubule cells and localization of accumulated alpha2-microglobulin in F344 rats during chronic exposure to unleaded gasoline or 2,2,4-trimethylpentane, Toxicol. Appl. Pharmacol., 101, 414-431.

Short, B.G., W.H. Steinhagen and J.A. Swenberg (1989b) Promoting effects of unleaded gasoline and 2,2,4-trimethylpentane on the development of atypical cell foci and renal tubular cell tumours in rats exposed to $N$-ethyl- $N$-hydroxyethylnitrosamine, Cancer Res.. 49, 6369-6378.

Solleveld, H.A., J.K. Haseman and E.E. McConnell (1984) Natural history of body weight gain, survival, and neoplasia in the F344 rat, J. Natl. Cancer Inst., 72, 929-940.

Stoerkel, S., B. Pannen, W.Thoenes, P.V. Steart, S. Wagner and D. Drenckhahn (1988a) Intercalated cells as a probable source for the development of renal oncocytomas, Virchows Arch. B Cell Pathol., 56, 185-189.

Stoerkel, S., P.V. Steart, D. Drenckhahn and W. Thoenes (1988b) The human chromophobe cell renal carcinoma; its probable relation to intercalated cells of the collecting duct, Virchows Arch. B Cell Pathol., 56, 237-245.

Swenberg. J.A., and B.G. Short (1987) Influence of cytotoxicity on the induction of tumours, in: B.E. Butterworth and T.J. Slaga (Eds.), Nongenotoxic Mechanisms in Carcinogenesis,
Banbury Report 25. Cold Spring Harbor Laboratory, Cold Spring Harbor, NY. pp. 151-161.

Swenberg, J.A., F.C. Richardson, J.A. Boucheron, F.H. Deal. S.A. Belinsky. M. Charbonneau and B.G. Short (1987) High- to low-dose extrapolation: critical determinants involved in the dose response of carcinogenic substances. Environ. Health Perspect. 76, 57-63.

Swenberg, J.A., B.G. Short, S.J. Borghoff, J. Strasser and M. Charbonneau (1989) The comparative pathobiology of alpha2-microglobulin nephropathy, Toxicol. Appl. Pharmacol., 97, 35-46.

Swenberg, J.A., N. Fedtke, T.R. Fennell and V.E. Walker (1990) Relationships between carcinogen exposure, DNA adducts, and carcinogenesis, in: D.B. Clayson. I.C. Munro, P. Shubik and J.A. Swenberg (Eds.), Progress in Predictive Toxicology, Elsevier, Amsterdam, pp. 161-184.

Thoenes, W., S. Stoerkel and H.J. Rumpelt (1985) Human chromophobe cell renal carcinoma, Virchows Arch. B Cell Pathol., 48, 207-217.

Thoenes, W., S. Stoerkel and H.J. Rumpelt (1986) Histopathology and classification of renal cell tumours (adenomas. oncocytomas and carcinomas). The basic cytological and histopathological elements and their use for diagnostics, Path. Res. Pract., 181, 125-143.

Thomas. C.. and D. Schmähl (1964) Zur Morphologie der Nierentumoren bei der Ratte, Z. Krebsforsch., 66, 125-137.

Toth. B. (1973) 1,1-Dimethylhydrazine (unsymmetrical) carcinogenesis in mice: light microscopic and ultrastructural studies on neoplastic blood vessels, J. Natl. Cancer Inst., 50, 181-194.

Tsuda, H., T. Sakata, S. Tamano, M. Okumura and N. Ito (1983) Sequential observations on the appearance of neoplastic lesions in the liver and kidney after treatment with $N$-ethyl- $N$-hydroxyethylnitrosamine followed by partial hepatectomy and unilateral nephrectomy, Carcinogenesis, 4, 523-528.

Tsuda, H., M.A. Moore, M. Asamoto, K. Satoh, S. Tsuchida, K. Sato, A. Ichihara and N. Ito (1985) Comparison of the various forms of glutathione-S-transferase with glucose-6phosphate dehydrogenase and $\gamma$-glutamyltranspeptidase as markers of preneoplastic and neoplastic lesions in rat kidney induced by $N$-ethyl- $N$-hydroxyethylnitrosamine, Jpn. Cancer Res., 76, 919-929.

Tsuda, H., H.J. Hacker, H. Katayama, T. Masui, N. Ito and P. Bannasch (1986) Correlative histochemical studies on preneoplastic and neoplastic lesions in the kidney of rats treated with nitrosamines, Virchows Arch. B Cell Pathol.. $51,385-404$.

Tsuda, H., M.A. Moore, M. Asamoto, T. Inoue, S. Fukushima, N. Ito, K. Satoh, Z. Amelizad and F. Oesch (1987) Immunohistochemically demonstrated altered expression of cytochrome P-450 molecular forms and epoxide hydrolase in $N$-ethyl- $N$-hydroxyethylnitrosamine-induced rat kidney and liver lesions, Carcinogenesis, 8, 711-717.

Turusov, V.A., V.A. Alexandrov and I.V. Tímoshenko (1980) Nephroblastoma and renal mesenchymal tumour induced in rats by $N$-nitrosoethyl- and $N$-nitrosomethylurea, Neoplasma, 27, 229--235. 